\title{
Elucidation of functional consequences of signalling pathway interactions
}

\author{
Adaoha EC Ihekwaba*†1, Phuong T Nguyen* ${ }^{* 1}$ and Corrado Priami ${ }^{1,2}$
}

Address: ${ }^{1}$ The Microsoft Research-University of Trento, Centre for Computational Systems Biology, Piazza Manci 17 Povo (Trento), Italy and 2Dept. of Information Engineering and Computer Science, University of Trento, Trento, Italy

Email: Adaoha EC Ihekwaba* - ihekwaba@cosbi.eu; Phuong T Nguyen* - nguyen@cosbi.eu; Corrado Priami - priami@cosbi.eu

* Corresponding authors †Equal contributors

Published: 6 November 2009

BMC Bioinformatics 2009, 10:370 doi:10.1186/1471-2105-10-370
Received: 8 May 2009

Accepted: 6 November 2009

This article is available from: http://www.biomedcentral.com/I47I-2/05/I0/370

(c) 2009 Ihekwaba et al; licensee BioMed Central Ltd.

This is an Open Access article distributed under the terms of the Creative Commons Attribution License (http://creativecommons.org/licenses/by/2.0), which permits unrestricted use, distribution, and reproduction in any medium, provided the original work is properly cited.

\begin{abstract}
Background: A great deal of data has accumulated on signalling pathways. These large datasets are thought to contain much implicit information on their molecular structure, interaction and activity information, which provides a picture of intricate molecular networks believed to underlie biological functions. While tremendous advances have been made in trying to understand these systems, how information is transmitted within them is still poorly understood. This ever growing amount of data demands we adopt powerful computational techniques that will play a pivotal role in the conversion of mined data to knowledge, and in elucidating the topological and functional properties of protein - protein interactions.

Results: A computational framework is presented which allows for the description of embedded networks, and identification of common shared components thought to assist in the transmission of information within the systems studied. By employing the graph theories of network biology such as degree distribution, clustering coefficient, vertex betweenness and shortest path measures - topological features of protein-protein interactions for published datasets of the $p 53$, nuclear factor kappa B (NF-KB) and GI/S phase of the cell cycle systems were ascertained. Highly ranked nodes which in some cases were identified as connecting proteins most likely responsible for propagation of transduction signals across the networks were determined. The functional consequences of these nodes in the context of their network environment were also determined. These findings highlight the usefulness of the framework in identifying possible combination or links as targets for therapeutic responses; and put forward the idea of using retrieved knowledge on the shared components in constructing better organised and structured models of signalling networks.

Conclusion: It is hoped that through the data mined reconstructed signal transduction networks, well developed models of the published data can be built which in the end would guide the prediction of new targets based on the pathway's environment for further analysis. Source code is available upon request.
\end{abstract}




\section{Background}

"Any classification in a division of objects into groups is based on a set of rules - it is neither true nor false (unlike, for example, a theory) and should be judged largely on the usefulness of the results" [1].

For many years, model organisms have been studied extensively by scientists as they tried to better understand the functional implication of processes initiated during cellular signalling, and how organisms can use this to respond to perturbations outside of the cell [2]. With the advent of high throughput experimentation, the identification and characterization of molecular components involved in transduction events became possible in a systematic way. In addition to this, the discovered interactions between each of these components promoted the reconstruction of reactions leading to signaling pathways. Thus, elucidating the functional consequences of these interactions will be crucial in understanding the ways in which cells respond to extra cellular cues and how they communicate with one another.

Activities of biological cells are regulated by proteins carrying signals that modify the expression of different genes at any given time, and these extra-cellular signals drive cell proliferation and programmed cell death via complex signal transduction circuits comprising of receptors, kinases, phosphatases, transcription factors and many others. It is unsurprising that many components of these signal transduction circuits are oncogenes or tumour suppressors, emphasizing the importance of understanding signalling in normal tissues and targeting aberrant signalling in diseases [3]. Signalling networks which are chiefly based on interactions between proteins are the means by which a cell converts an external signal (e.g. stimulus) into an appropriate cellular response (e.g. cellular rhythms - periodic biological process observed in cell cycles or day-night cycles (circadian rhythms) of animals and plants) [4-6]. It is from the resulting basic cellular responses that complex behaviour in multi-cellular organisms emerges.

Signal transduction pathways have typically been drawn as separate linear entities, however it has become increasingly clear that signalling pathways are extensively interconnected and are embedded in networks with common protein components and cross talk with other networks [7-11]. In addition to this, signal transduction networks do not depend merely on the shifting of relevant protein concentrations from one steady state level to another, rather, the signals often have a significant temporal variation that carries much more information that is propagated in a complex manner through the networks [12-15].

Traditionally, study of the complex behaviour of networks require dynamic models that contain both the biochemi- cal reactions as well as their rate constant counterparts [16-19]. This information is usually not accessible directly through experiments for systems less well studied. Fortunately for many biological systems partial prior knowledge about the connectivity patterns of the networks is becoming available and readily stored in databases [2023], even though the detailed mechanisms still remain undiscovered. An important goal of this research therefore is to attain a reconstruction of the network of interactions that gives rise to signalling pathways in a biologically meaningful way, which in turn allows the mathematical analysis of the emerging properties of the network [24,25].

So far, a great deal of data has accumulated on signalling systems and these large datasets are thought to contain much information on the structure of their underlying networks. However, this information is hidden and requires advanced algorithms and methods, such as data mining and graph theories of network biology to make sense of it all [26-28]. Data mining deals with the discovery of hidden knowledge, unexpected patterns and new rules [29]; nevertheless, there are some limitations with this technique. A fundamental issue is that biological data repositories are normally presented in heterogeneous and unstructured forms [30-33]. Therefore, there is a great need to develop effective data mining methodologies to extract, process, integrate and discover useful knowledge from multiple data sources [34]. The retrieved knowledge can then be better organized and structured to develop models, which in the end, would guide the prediction of new targets based on the pathway's environment [24,26$28,35,36]$.

In this report, we present a systems analysis framework to examine how protein-protein interactions within these systems relate to multi-cellular functions, and how high throughput technologies allow the study of the different aspects of signalling networks for modelling. We assume that since mammalian cells are constantly remodelling their transcriptional activity profiles in response to a combination of inputs, the understanding of their coordinated responses have been lacking, and in essence requires a framework which examines the system or systems by extracting information on their topological and functional properties. An example of a system activated in response to a variety of signals is the $N F-\kappa B$ pathway [19,37-40] (a family of proteins which functions as DNAbinding proteins and transcription factors); the disruption of which in recent years have been shown to contribute towards the many human diseases presently known. We also know from literature [41-43] that the NF-кB network does not exist in isolation, since many of its mechanisms have been shown to integrate their activity with other cell signalling networks. Such as the p53 system 
[17,44-49] (another transcriptional activator that plays an important role in the regulation of apoptosis) and the E2F-1 [50-53] - a cell cycle transcriptional target that controls the expression of a number of genes needed for DNA synthesis and progression into $S$ phase $[46,49,54-59]$. It is thought that the cooperation between $\mathrm{p} 53, \mathrm{NF}-\mathrm{\kappa B}$ and E2F-1 is most likely to reflect on their ability to function together to induce expression of target genes regulated by promoters containing $\mathrm{p} 53, \mathrm{NF}-\mathrm{\kappa B}$ and E2F-1 binding sites $[53,60,61]$, since target genes translated to proteins in one way or another affect the individual system in a positive or negative way.

To capture the possible events involved in the pathways, only proteins involved in the oscillatory feedback loops of the systems were considered - which are ubiquitous feature of the biological examples given which can be adapted to yield distinct system level properties $[16,17,40,62]$. To generate the networks, the molecular components and their interactions were extracted from publicly available datasets [20-23]. In addition, associations of these networks with some cell cycle proteins, in particular, the G1/ $S$ phase cell cycle proteins $[63,64]$ were also examined. Cell cycle proteins were considered since previously published literature showed some of its proteins to be activated by one pathway and to be relevant for the regulation of another [44,65-70]; and thus may be useful in showing a level of complexity not visible by looking at the NF- $\mathrm{KB}$ and p53 systems alone. We next identified key nodes of significant influence in the isolated systems investigated using some graph theories of network biology, namely, degree, vertex betweenness, and clustering coefficient measures. We used shortest paths calculation to find connecting nodes, most likely responsible for the propagation of transduction signals across the networks. And cross referencing them with reference databases, the interpretation of the functional properties of these key nodes, as well as, the highly ranked connecting nodes within the systems were realised. The idea is that through the data mined reconstructed signal transduction pathways which are comparable to the previously modelled networks of the real system, a phenomenological model of all the published data can be derived from which the key components of the system can be highlighted for further analysis. In fact, as we will show in this report, it is possible to reconstruct signalling networks in this way without additional constraint.

\section{Methods}

The development of high-throughput molecular assay technologies, as well as breakthroughs in information processing and storage technologies provide integrated views of biological and medical information. Databases enabling systematic data mining on bio-molecular interactions, pathways and molecular disease associations are becoming increasingly available, which it is hoped will facilitate the understanding of the dynamics of biological function in complex diseases. Summarised below are descriptions of the analytical methods used in this study see Figure 1 for a schematic representation of the framework.

\section{Definition of Reference Databases}

Over the last few years many of the experimental data from gene expression studies have been made freely available for academic research in the form of reference databases [20-23] of which several exist. These different databases have their strengths and weaknesses and there is no universal method best for storing these data sets. A number of different approaches have been used to extract signalling data and integrate them for biologically valid conclusions to be drawn from the vast and comprehensive data sets available $[71,72]$. Table 1 lists a description of the individual databases used in this study, each of which

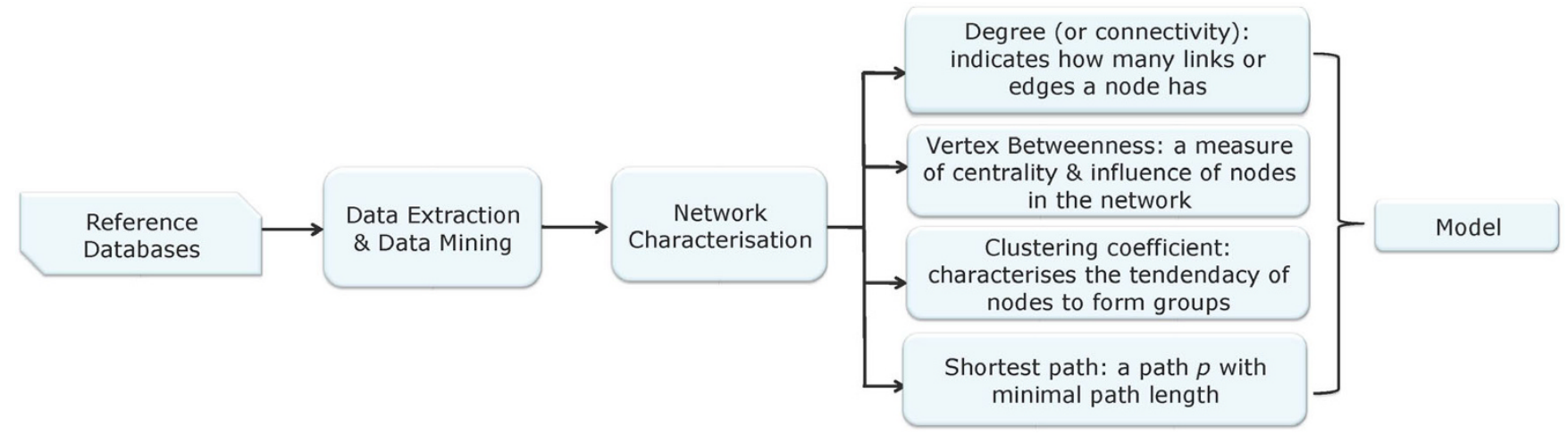

Figure I

A Schematic representation of the modelling framework introduced. 
Table I: Reference databases used for data retrieval during the investigation

\begin{tabular}{|c|c|c|c|c|}
\hline Database & Description & URL & Statistics & Data extracted \\
\hline $\begin{array}{l}\text { Uniprot } \\
{[20]}\end{array}$ & $\begin{array}{l}\text { comprehensive, high-quality and } \\
\text { freely accessible resource of protein } \\
\text { sequence and functional information. }\end{array}$ & http://www.uniprot.org & 220,325 entries & $\begin{array}{l}\text { function,, post-translation } \\
\text { modification, location, } \\
\text { developmental stage, etc. }\end{array}$ \\
\hline $\begin{array}{l}12 \mathrm{~d} \\
{[21]}\end{array}$ & $\begin{array}{l}\text { on-line database of known and } \\
\text { predicted mammalian and eukaryotic } \\
\text { protein-protein interactions }\end{array}$ & http://ophid.utoronto.ca/ & $\begin{array}{l}424,066 \text { entries } \\
(92,561 \text { for human })\end{array}$ & protein interaction \\
\hline $\begin{array}{l}\text { Reactome } \\
{[22]}\end{array}$ & $\begin{array}{l}\text { curated resource of core pathways } \\
\text { and reactions in human biology. }\end{array}$ & $\begin{array}{l}\text { http:// } \\
\text { www.reactome.org }\end{array}$ & 928 pathways for human & Pathway \\
\hline $\begin{array}{l}\text { PID } \\
{[23]}\end{array}$ & curated pathway and interactions & http://pid.nci.nih.gov/ & I33 pathways & Pathway \\
\hline
\end{tabular}

was used to retrieve information related to the proteins considered. These databases contain information on proteins, protein interactions and biological processes.

\section{Data extraction and data-mining}

The concerted efforts of genetics, molecular biology, biochemistry and physiology have led to the accumulation of an enormous amount of data on molecular components of signalling networks reported in the literature or stored in databases [73]. The availability of these vast amounts of data provides an opportunity for investigating further the design principles underlying structure and dynamics of signalling networks $[71,72,74]$. However, these data are diverse and dispersed in different databases. For this reason, data mining is employed and takes the responsibility of mining this amount of data in the hope that it will return useful hypotheses supporting life sciences. Due to its capability of processing different kinds of data, data mining has the ability to integrate these spread-out data in a unified framework thus solving more efficiently the problems that may arise due to their differences $[29,30,32]$.

We started by looking into four databases: Universal Protein Resource (Uniprot), Interologous Interaction Database (i2d), Reactome and Pathway Interaction Database $(P I D)$, which we have listed in Table 1 . Since different databases have different names for each entry, the Uniprot name for identifying proteins was used as the standard and thus all protein names were converted accordingly to

Table 2: Proteins and pathways considered in the study

\begin{tabular}{|c|c|c|c|}
\hline Network & Uniprot accession & Uniprot entry name & Alternative name \\
\hline \multirow[t]{4}{*}{ p53 pathway } & P04637 & P53_HUMAN & p53 \\
\hline & Q00987 & MDM2_HUMAN & $\mathrm{mdm} 2$ \\
\hline & P38936 & CDNIA_HUMAN & p2I \\
\hline & Q8N726 & CD2A2_HUMAN & p I 4ARF \\
\hline \multirow[t]{14}{*}{ NF- $\kappa B$ pathway } & 000221 & IKBE_HUMAN & NF- $\kappa B$ inhibitor epsilon \\
\hline & OI4920 & IKKB_HUMAN & IKK2 \\
\hline & OI5III & IKKA_HUMAN & IKKI \\
\hline & PI9838 & NFKBI_HUMAN & Nuclear factor NF-кB pl05 subunit \\
\hline & P25963 & IKBA_HUMAN & IKB-alpha \\
\hline & Q00653 & NFKB2_HUMAN & Nuclear factor NF- $\kappa B$ pl00 subunit \\
\hline & Q0I20I & RELB_HUMAN & Transcription factor RelB \\
\hline & Q04206 & TF65_HUMAN & Transcription factor p65 (RelA) \\
\hline & Q04864 & REL_HUMAN & C-Rel protein \\
\hline & Q14164 & IKKE_HUMAN & Inhibitor of nuclear factor $\kappa B$ kinase subunit epsilon \\
\hline & Q15653 & IKBB_HUMAN & NF-kappa-B inhibitor beta \\
\hline & Q96HDI & CRELI_HUMAN & Crell \\
\hline & Q6UXHI & CREL2_HUMAN & Crel2 \\
\hline & Q9Y6K9 & NEMO_HUMAN & $\mathrm{IKK} \gamma$ \\
\hline GI/S phase cell & P24385 & CCNDI_HUMAN & Cyclin DI \\
\hline \multirow[t]{3}{*}{ cycle proteins } & Q01094 & E2FI_HUMAN & $\mathrm{E} 2 \mathrm{~F}-\mathrm{I}$ \\
\hline & P06400 & RB_HUMAN & $\mathrm{Rb}$ \\
\hline & P46527 & CDNIB_HUMAN & $\mathrm{P} 27$ \\
\hline
\end{tabular}

\footnotetext{
The proteins have been listed according to their Uniprot accession names.
} 
Table 3: Pathways and biological processes information retrieved from Reactome database

\begin{tabular}{lll}
\hline Uniprot accession & Uniprot entry name & Pathway \\
\hline P25963 & IKBB_HUMAN & [2 processes]: Signalling in Immune system; Signalling by NGF \\
Q15653 & REL_HUMAN & Signalling in Immune system \\
O151II & IKKB_HUMAN & [2 processes]: Signalling in Immune system; Signalling by NGF \\
O14920 & IKKE_HUMAN & [2 processes]: Signalling in Immune system; Signalling by NGF \\
PI9838 & IKBA_HUMAN & [2 processes]: Signalling in Immune system; Signalling by NGF \\
Q00653 & IKBE_HUMAN & Signalling in Immune system \\
Q04206 & IKBZ_HUMAN & [2 processes]: Signalling in Immune system; Signalling by NGF \\
P04637 & P53_HUMAN & Cell Cycle Checkpoints \\
P38936 & CDNIA_HUMAN & [3 processes]: Cell Cycle Checkpoints; Cell Cycle, Mitotic; DNA Replication \\
Q00987 & MDM2_HUMAN & [2 processes]: Cell Cycle Checkpoints; Signalling by NGF \\
P46527 & CDNIB_HUMAN & Signalling by NGF \\
\hline
\end{tabular}

Reactome can either be directly browsed or queried by text search using, for instance using UniProt accession numbers, to identify events or pathways considered search proteins are involved in.

their Uniprot counterparts. In addition, in the Uniprot database, protein information is published for a widerange of organisms and curated from different sources. A search for p53 in Uniprot returns 1,624 results, such as [Uniprot:P04637] (P53_HUMAN) for human, [Uniprot:P02340] (P53_MOUSE) for mouse, [Uniprot:P13481] (P53_CERAE) for green monkey. To assure the proteins extracted from Uniprot are the exact proteins from the organism of interest, a form of verification was implemented, where the identity of the mined data is confirmed through a form of literature search. This step avoids the confusion and ambiguity that often occurs when mining and integrating multiple data. Table 2 lists the search proteins considered in the study (highlighted proteins are proteins reported to be activated in one system and involved in the regulation of another).

Using the i2d database, information on protein-protein interactions was extracted. Such information is potentially useful in identifying proteins and their families, the interplay with their interacting partners, the influence of certain proteins in a network and key regulatory relationships which are most influenced by extracellular signals. More comprehensive knowledge concerning the proteins of interest and their connector proteins, for example, biological process, cellular component, coding sequence diversity, developmental stage, disease, domain, ligand, molecular function and post-translation modification were also extracted. For elucidating the functional consequences of the interactions, the Reactome database which gives pathway information by combining with graph information of the PID database - was the database of choice. Table 3 presents a list of pathways and/or processes the explored proteins were revealed to be involved in. The data mining implementation was done in Perl programming language http://www.perl.org/ and derived from BioPython library http://biopython.org/wiki/ Main Page.

\section{Network Biology}

The actions of specific proteins in a network have been investigated in this report. A network can be described as a series of nodes/vertices that are connected to each other by links. Formally it was referred to as a graph and the links as edges [26,75-77]. The nodes in biological networks are the gene products/proteins and the links the interactions between two components [13,78]. A number of metrics have been used to characterise the networks of the systems studied:

- The first, the degree (or connectivity) of a node/vertex $k$, indicates how many links/edges the node has to the other nodes. Of particular importance is the degree

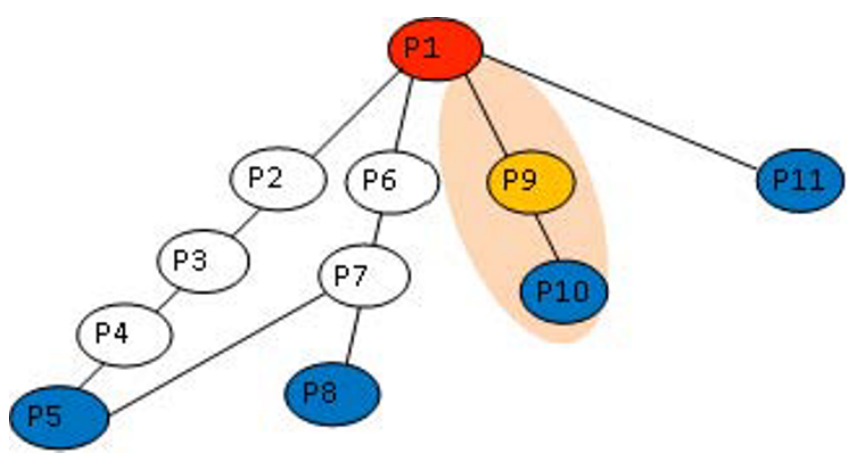

Figure 2

Diagram of the shortest path calculation. An Illustration showing how the shortest path discussed in the report is calculated. It is assumed that; from PI to P5: $p_{1}=(\mathrm{PI}-\mathrm{P} 6-\mathrm{P} 7-$ $\mathrm{P} 5)$ and $l_{1}=3$. From PI to P8: $p_{2}=(\mathrm{PI}-\mathrm{P} 6-\mathrm{P} 7-\mathrm{P} 8)$ and $l_{2}=3$. From PI to PI0: $p_{3}=(\mathrm{PI}-\mathrm{P9}-\mathrm{PIO})$ and $l_{3}=2$. From PI to PII: $p_{4}=(\mathrm{PI}-\mathrm{PII})$ and $I_{4}=\mathrm{I}$. 
distribution $P(k)$, which measures the probability that a selected node has exactly $k$ links. The degree distribution is used to distinguish between the different classes of network (which has not been reported in this account).

- The second, vertex betweenness $\left(B_{i}\right)$ is a measure of the centrality and influence of nodes in the networks [79-82].

- The third, average clustering coefficient $C(k)$, characterises the overall tendency of nodes to form clusters or groups; and $C(k)$ the average clustering coefficient of all nodes with $k$ links is an important measure of the network structure [15].

- And finally, the shortest path, which is found between two vertices (or nodes) such that the sum of the weights of its constituent edges is minimized $[82,83]$.

A graph $G(E, V)$ consists of a set of vertices $(V)$ and a set of edges (E) between them. An edge $e_{i j}$ connects vertex $v_{i}$ with vertex $v_{j}$. Here, undirected graph is investigated since our studied protein interaction networks are undirected. An undirected graph has the property that $e_{i j}$ and $e_{j i}$ are considered identical. Therefore, the neighbourhood $\mathrm{N}$ for a vertex $v_{i}$ is defined as it's immediately connected neighbours in Eq. (1):

$$
N_{i}=\left\{v_{j}: e_{i j} \in E\right\}
$$

where the degree $k_{i}$ of a vertex is defined as the number of vertices $\left|N_{i}\right|$, in its neighbourhood $N_{i}$.

The betweenness centrality of a vertex $v_{i}$ is defined as the number of shortest paths between pairs of other vertices that run through $v_{i}$ as Eq. (2):

$$
B_{i}=\frac{\sum_{j>k} g_{j k}(i)}{g_{j k}}
$$

where $i \neq j \neq k, g_{j k}$ is the number of equally shortest paths between nodes $v_{j}$ and $v_{k^{\prime}}$ and $g_{j k}(i)$ the number of the shortest paths where node $v_{i}$ is located [84].
The clustering coefficient $C_{i}$ for a vertex $v_{i}$ is given by the proportion of links between the vertices within its neighbourhood divided by the number of links that could possibly exist between them [15]. Therefore, if a vertex $v_{i}$ has $k_{i}$ neighbours, $k_{i}\left(k_{i}-1\right) / 2$ edges could exist among the vertices within the neighbourhood where the clustering coefficient for undirected graphs can be defined as Eq.(3):

$$
C_{i}=\frac{2\left|\left\{e_{j k}\right\}\right|}{k_{i}\left(k_{i}-1\right)}: v_{j}, v_{k} \in N_{i}, e_{j k} \in E
$$

For the shortest path, given a real-value weight function $f$ : $E \rightarrow \mathbf{R}$, and a start node $v_{i}$ of $V$, we find a path $p$ of $P$ (the set of paths) from $v_{i}$ to each $v_{j}$ of $V$ if present (Eq. (4), so that

$\sum_{p \in P} f(p)$ is minimal among all paths connecting $v_{i}$ and $v_{j}$.

If the protein-protein interaction networks here constitute an unweighted graph, the weight function $f$ can be considered as a path length $l$ (the number of edges in path $p$ ). In this case, the shortest path problem is to find a path $p$ having the minimal path length. A Breadth-First Search algorithm $[82,83]$ has been employed to find the shortest paths between two nodes (the starting node $v_{i}$ and destination node $v_{j}$ ) (see Figure 2 ). The shortest paths may have different path lengths $(l=1, l=2, l=3, l=4$, etc.). In the example shown in Figure 2, there are different shortest paths from start node $P 1$ to destination nodes (P5, P8, $P 10, P 11)$ via different connector nodes $(P 6, P 7, P 9)$. If the path length is 1 , this signifies a direct connection, where two nodes are directly connected (e.g., P1 and P11). For the shortest paths with $l=2$, there are three nodes: a start node (P1), a connector node (P9), and a destination node (P10). Using this form of analysis the path lengths were used to obtain knowledge on the functional interactions between the proteins. For the purpose of this report we will only discuss findings for the shortest paths between two nodes of interest with path length $l=1$ or $l=2$; their connector nodes and their frequency ranking $\left(f_{i}\right)$ [see Additional file 1: Suppl. 1-5 for the full list of shortest

Table 4: Statistical information on the nodes and interactions retrieved for the networks

\begin{tabular}{llll}
\hline Network & Number of nodes & Number of interactions & Number of articulation points \\
\hline p53 & 436 & 506 & 7 \\
NF- $\kappa B$ & 788 & 1352 & 15 \\
Cell cycle - Cyclin DI, Rb, E2F-I, p27 & 527 & 299 & 4 \\
NF- $\kappa$ B and p53 & 1105 & 1834 & 18 \\
NF- $\kappa$ B, p53 and Rb, E2F-I & 1208 & 2032 & 20 \\
NF- $\kappa B, p 53$ and Cyclin DI, Rb, E2F-I, p27 & 1239 & 2127 & 22 \\
\hline
\end{tabular}


Table 5: Degree and clustering coefficient values calculated for the p53 and NF-kB networks

\begin{tabular}{|c|c|c|c|c|c|c|c|}
\hline \multicolumn{4}{|c|}{ Network p53 } & \multicolumn{4}{|c|}{ Network NF- $k B$} \\
\hline $\begin{array}{l}\text { Uniprot } \\
\text { accession }\end{array}$ & $\begin{array}{l}\text { Uniprot entry } \\
\text { name }\end{array}$ & Degree & $\begin{array}{l}\text { Clustering } \\
\text { coefficient }\end{array}$ & $\begin{array}{l}\text { Uniprot } \\
\text { accession }\end{array}$ & $\begin{array}{l}\text { Uniprot entry } \\
\text { name }\end{array}$ & Degree & $\begin{array}{l}\text { Clustering } \\
\text { coefficient }\end{array}$ \\
\hline P04637 & P53_HUMAN & 300 & $9.10 \mathrm{E}-04$ & Q14164 & IKKE_HUMAN & 324 & I.90E-04 \\
\hline Q00987 & MDM2_HUMAN & 72 & 0.0133 & Q04206 & TF65_HUMAN & 186 & 0.01796 \\
\hline P38936 & CDNIA_HUMAN & 72 & 0.00509 & Q9Y6K9 & NEMO_HUMAN & 157 & 0.01764 \\
\hline Q8N726 & CD2A2_HUMAN & 43 & 0.00664 & Q00653 & NFKB2_HUMAN & 145 & 0.03218 \\
\hline P53999 & TCP4_HUMAN & 12 & 0 & PI9838 & NFKB I_HUMAN & 118 & 0.04578 \\
\hline Q9Y3B4 & PMI4_HUMAN & 10 & 0 & P25963 & IKBA_HUMAN & 85 & 0.05546 \\
\hline P49459 & UBE2A_HUMAN & 3 & 0.66667 & 014920 & IKKB_HUMAN & 75 & 0.07279 \\
\hline Q16665 & HIFIA_HUMAN & 3 & 0.66667 & Q15653 & IKBB_HUMAN & 73 & 0.06963 \\
\hline P06748 & NPM_HUMAN & 3 & 0.66667 & OI5III & IKKA_HUMAN & 71 & 0.08089 \\
\hline P25490 & TYYI_HUMAN & 3 & 0.66667 & Q0I20I & RELB_HUMAN & 64 & 0.06399 \\
\hline P62988 & UBIQ_HUMAN & 3 & 0.66667 & 000221 & IKBE_HUMAN & 48 & 0.11702 \\
\hline P51959 & CCNGI_HUMAN & 3 & 0.66667 & Q04864 & REL_HUMAN & 38 & 0.14794 \\
\hline Q92793 & CBP_HUMAN & 3 & 0.66667 & Q96HDI & CRELI_HUMAN & 12 & 0.68182 \\
\hline P6208I & RS7_HUMAN & 3 & 0.66667 & P07437 & TBB5_HUMAN & 12 & 0.68182 \\
\hline Q99816 & TSIOI_HUMAN & 3 & 0.66667 & P62158 & CALM_HUMAN & 12 & 0.68182 \\
\hline
\end{tabular}

The table is arranged in descending order. Only the first fifteen proteins within the network with high degree values are listed.

paths with other path lengths]. A node is said to have a high frequency if there is an increase in the number of paths passing through it; thus a high frequency node may be the centre of the networks' cross talk. For a given set of 2-length shortest paths $[26,85]\left\{p_{1}, p_{2}, p_{3}, \ldots p_{n}\right\}$ between two sets of nodes $V_{i}$ and $V_{j}$, with $v_{1}, v_{2}, v_{3}$ as connectors of those paths, if frequency $f_{1}$ of $v_{1}=2$ (if $v_{1}$ is the connectors of two paths); $f_{2}=10$ (if $v_{2}$ is the connector of ten paths); $f_{3}=5$ (if $v_{3}$ is the connector of five paths); then the results of the ranking is $v_{2}-v_{3}-v_{1}$. The highly ranked nodes obtained, is then suggested to be the most important nodes within the network.

Network biology computation was implemented in $\mathrm{CoS}-$ BiLab-Graph http://www.cosbi.eu/index.php/research/ prototypes/overview. CoSBiLab-Graph is a tool suitable for a variety of tasks on graphs like construction, visualisation, and modification. CoSBiLab-Graph can be used to calculate measures, run algorithms and layout graphs. The network visualisation is performed by the software NAViGaTOR ((Network Analysis, Visualization, \& Graphing TORonto)) http://ophid.utoronto.ca/navigator/. NAViGaTOR is the add-in software package of i2d database, and thus supports the simulation of the protein interaction networks extracted from $i 2 d$ in this report. Other network analysis tools used are Social Network Analysis Software http://www.analytictech.com/, and Centralities in Biological Networks http://centibin.ipk-gatersle ben.de/.

Table 6: Degree and clustering coefficient values calculated for the cell cycle network

\begin{tabular}{cccc}
\hline Uniprot accession & Uniprot entry name & Degree & Clustering coefficient \\
\hline P06400 & RB_HUMAN & $\mathbf{1 5 6}$ & $\mathbf{0 . 0 0 2 3 2}$ \\
P46527 & CDNIB_HUMAN & $\mathbf{0 . 0 0 2 4 5}$ \\
P24385 & CCNDI_HUMAN & $\mathbf{5 0}$ & $\mathbf{0 . 0 1 3 3 0}$ \\
Q01094 & E2FI_HUMAN & $\mathbf{4 8}$ & $\mathbf{0 . 0 1 4 1 8}$ \\
Q13309 & SKP2_HUMAN & $\mathbf{4 8}$ & 0.33333 \\
P78396 & CCNAI_HUMAN & 3 & 0.33333 \\
P08047 & SPI_HUMAN & 3 & 0.66667 \\
P2494I & CDK2_HUMAN & 3 & 0.66667 \\
P38398 & BRCAI_HUMAN & 3 & 0.66667 \\
PII802 & CDK4_HUMAN & 0.66667 \\
P20248 & CCNA2_HUMAN & 3 & 0.00000 \\
Q9NQX5 & NPDCI_HUMAN & 3 & 0.00000 \\
P00519 & ABLI_HUMAN & 2 & 0.00000 \\
P33993 & MCM7_HUMAN & 2 & 0.00000 \\
P3028I & CCND3_HUMAN & 2 & 0.00000
\end{tabular}




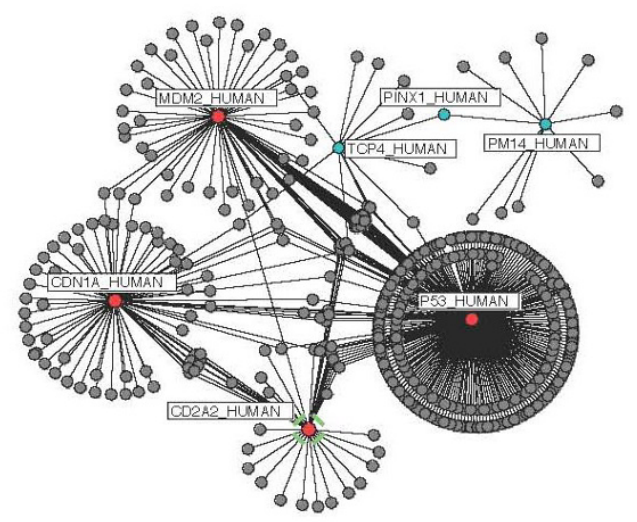

A

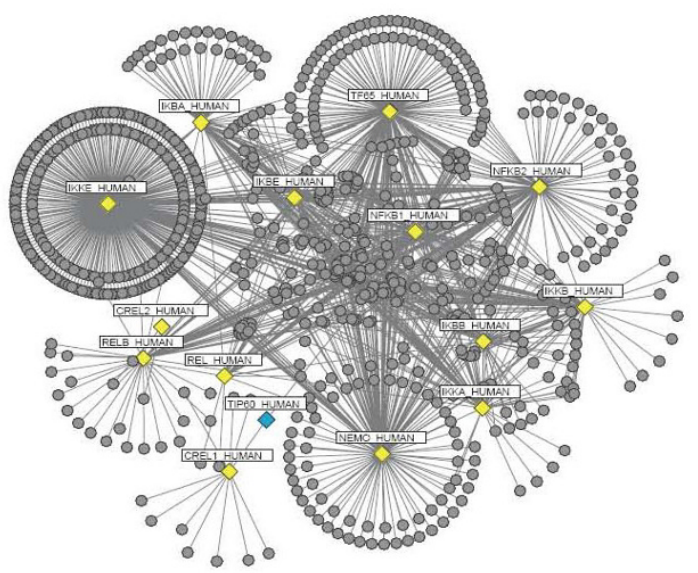

B

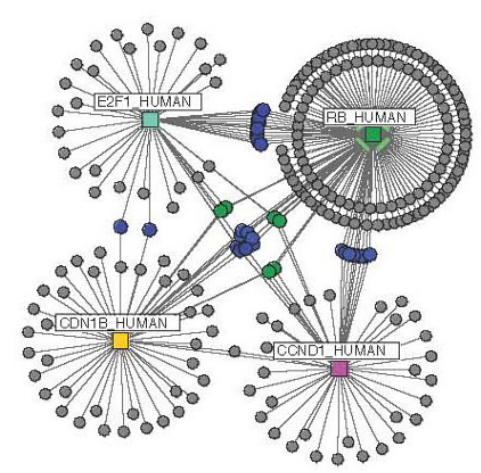

C

\section{Figure 3}

Network representation of isolated $\mathbf{p 5 3}, \mathbf{N F - \kappa B}$ and cell cycle systems. A graphical representation of the $(A) p 53,(B)$ NF- $\kappa B$, and $(\mathbf{C})$ the GI/S transition phase of the cell cycle $\{$ RB_HUMAN, E2FI_HUMAN, CDNIB_HUMAN and CCNDI_HUMAN\} networks. The proteins are represented in the form of nodes, and their interactions in the form of edges. For the cell cycle network (C), the shared components linking RB_HUMAN, E2FI_HUMAN, CDNIB_HUMAN and CCNDI_HUMAN to one another are highlighted (in green), and are six in number (i.e. three pairs). RB_HUMAN, CCNDI_HUMAN and CDNIB_HUMAN connect with each other by CDK4_HUMAN and CDK2_HUMAN. RB HUMAN, E2FI_HUMAN and CDNIB_HUMAN are linked together by CCNAI_HUMAN and SKP2_HUMAN. And finally RB_HUMAN, CDNIB_HUMAN, E2FI_HUMAN and CCNDI_HUMAN link up with BRCAI_HUMAN and SPI_HUMAN as their connecting components. 
Table 7: Vertex betweenness values calculated for $\mathrm{p} 53, \mathrm{NF}-\mathrm{kB}$ and cell cycle networks

\begin{tabular}{|c|c|c|c|c|c|c|c|c|}
\hline \multicolumn{3}{|c|}{ Network p53 } & \multicolumn{3}{|c|}{ Network NF- $k B$} & \multicolumn{3}{|c|}{ Cell Cycle } \\
\hline $\begin{array}{l}\text { Uniprot } \\
\text { accession }\end{array}$ & $\begin{array}{l}\text { Uniprot entry } \\
\text { name }\end{array}$ & $B_{i}$ & $\begin{array}{l}\text { Uniprot } \\
\text { accession }\end{array}$ & $\begin{array}{l}\text { Uniprot entry } \\
\text { name }\end{array}$ & $B_{i}$ & $\begin{array}{l}\text { Uniprot } \\
\text { accession }\end{array}$ & $\begin{array}{l}\text { Uniprot entry } \\
\text { name }\end{array}$ & $B_{i}$ \\
\hline P04637 & P53_HUMAN & 81612.87 & Q14164 & IKKE_HUMAN & 166771.25 & P06400 & RB_HUMAN & 26218.55 \\
\hline P38936 & $\begin{array}{l}\text { CDNIA } \\
\text { HUMAN }\end{array}$ & 22279.58 & Q04206 & TF65_HUMAN & 70319.46 & P24385 & $\begin{array}{l}\text { CCNDI- } \\
\text { HUMAN }\end{array}$ & 9196.14 \\
\hline Q00987 & MDM2_HUMAN & 18352.39 & Q9Y6K9 & NEMO_HUMAN & 60543.29 & Q01094 & E2FI_HUMAN & 8081.61 \\
\hline Q8N726 & CD2A2_HUMAN & 9223 & Q00653 & NFKB2_HUMAN & 48010.40 & P46527 & CDNIB_HUMAN & 7318.69 \\
\hline P53999 & TCP4_HUMAN & 6801.47 & PI9838 & NFKBI_HUMAN & 40763.53 & P2494I & CDK2_HUMAN & $148 \mid .39$ \\
\hline Q96BK5 & PINXI_HUMAN & 4250 & P25963 & IKBA_HUMAN & 40680.12 & PII802 & CDK4_HUMAN & $|48| .39$ \\
\hline Q9Y3B4 & PMI4_HUMAN & 3870 & QI5653 & IKBB_HUMAN & 21318.82 & Q13309 & SKP2_HUMAN & 1195.79 \\
\hline P68400 & CSK2I_HUMAN & |706.|I & QOI20I & RELB_HUMAN & 17557.99 & P78396 & CCNAI_HUMAN & II95.79 \\
\hline P20226 & TBP_HUMAN & 1607.64 & 014920 & IKKB_HUMAN & I 5356.68 & P38398 & BRCAI_HUMAN & 872.01 \\
\hline Q09472 & EP300_HUMAN & 1607.64 & OI5III & IKKA_HUMAN & | 4387.00 & P08047 & SPI_HUMAN & 872.01 \\
\hline P4I 235 & HNF4A_HUMAN & 1192.02 & 000221 & IKBE_HUMAN & $12109.0 \mid$ & Q9Y3II & FBX7_HUMAN & 614.12 \\
\hline $\mathrm{PI} 2004$ & PCNA_HUMAN & 514.08 & Q92993 & KAT5_HUMAN & 8503 & Q00526 & CDK3_HUMAN & 614.12 \\
\hline P21675 & TAFI_HUMAN & 415.62 & Q96HDI & CRELI_HUMAN & 7785 & P20248 & CCNA2_HUMAN & 614.12 \\
\hline P06748 & NPM_HUMAN & 363.33 & Q04864 & REL_HUMAN & 6563.01 & P3028I & CCND3_HUMAN & 614.12 \\
\hline P08238 & HS90B_HUMAN & 363.33 & P07437 & TBB5_HUMAN & 3982.81 & P30279 & CCND2_HUMAN & 614.12 \\
\hline
\end{tabular}

Results obtained by vertex betweenness produced similar results to the degree of connectivity index reported in Tables 5 and 6 .

\section{Results and Discussion}

Recognising that individual signalling pathways do not act in isolation, an integrated approach to investigate the dynamic relationships between components, their organisation and regulation in signalling systems was undertaken. We started by searching the i2d database (containing 92,561 human protein interactions) for the proteins of interest. This search retrieved a total of 1,881 protein-protein interactions for components of p53 and NF- $\kappa$ B networks (see Table 2). To increase the confidence in the extracted interactions information, we excluded 47 interactions shown to have been derived from other organisms (other than human) by homologous methods, so that the number of protein interactions obtained involving both the NF- $\mathrm{B}$ and $\mathrm{p} 53$ networks consists of 1,834 interactions. Information on protein-protein interactions within the NF- $\mathrm{B}$ and p53 pathways were also retrieved and analysed. Finally, the interlinking connections between the NF- $\kappa \mathrm{B}$ and p53, and proteins involved in the G1/S phase of the cell cycle (in particular, RB_HUMAN, CCND1_HUMAN, CDN1B_HUMAN, CD2A2_HUMAN, E2F1_HUMAN and CDN1A_HUMAN) were also investigated (see Table 4 for statistical information retrieved for the networks).

\section{Network of Interactions}

Following data extraction, descriptive analysis of the data was performed. The degree, betweenness and cluster coefficient values for the network's components were calculated in order to ascertain the level of connectivity of the three systems. Figure 3 illustrates the molecular interactions obtained for the NF- $\kappa \mathrm{B}, \mathrm{p} 53$ and the $\mathrm{G} 1 / \mathrm{S}$ phase cell cycle, respectively. Figure $3 \mathrm{~A}$ and Table 4 show for the proteins in the p53 network, 506 interactions and 436 nodes. Seven of which are articulation points (four original search nodes (in red) and three other associated nodes obtained from the extraction process (in cyan)). Articulation nodes (or cut vertex) [86,87] are nodes that play an important role in a network, where the removal of the node may drastically alter the network topology leading to it's fragmentation. Conversely, for the NF- $\kappa \mathrm{B}$ network (see Table 4 \& Figure 3B) 788 nodes and 1,352 interactions were observed. The articulation points were fifteen in number, fourteen of which were the search proteins considered (in yellow) and an associated TIP60_HUMAN (in cyan) obtained during the extraction process. A subset of the highest connectivity or degree values are shown in Table 5 and 6 [see Additional file 1: Suppl. 6-10 for connectivity values obtained for nodes not included in the Tables]. We found that for the three networks examined, the calculated degree for the initial list of proteins, with the exception of the CREL2 protein in the NF- $\kappa$ B network (Table 2), were discovered to be much higher than the associated proteins found during the mining process; and therefore underscored the central role of the initial list within their individual networks (search proteins highlighted on Table 5 and 6; please note other nodes TIP60_HUMAN in the NF- $\kappa \mathrm{B}$ network (Figure $3 \mathrm{~B}$ ), and TCP4_HUMAN, PINX1_HUMAN and PM14_HUMAN in the p53 network (Figure $3 \mathrm{~A}$ ) - are associated articulation points).

The highest-degree node (or connectivity) uncovered for the NF- $\kappa$ B network was IKKE_HUMAN, a protein respon- 


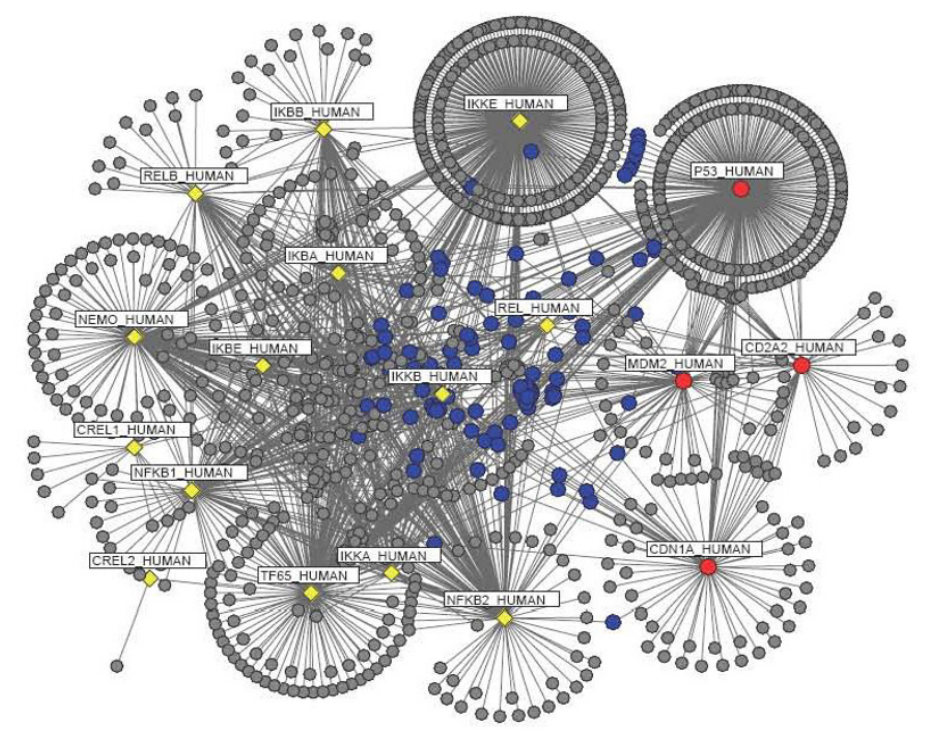

A

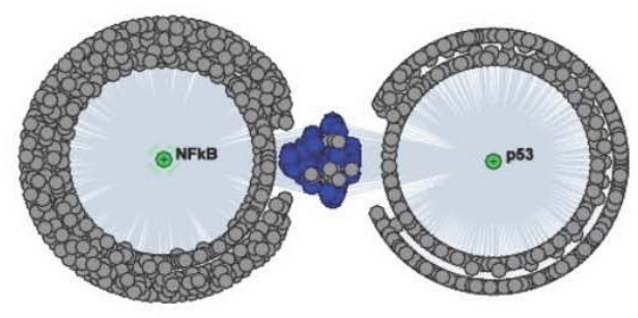

B

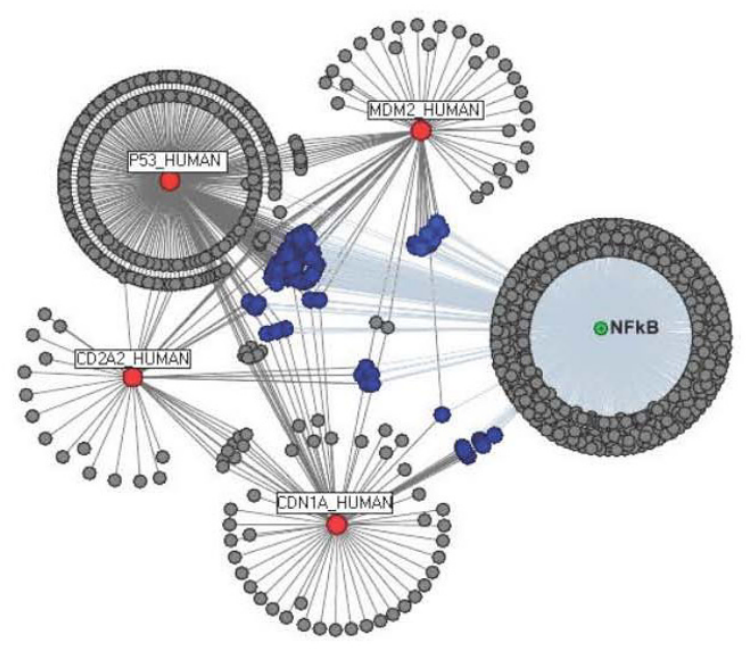

C

\section{Figure 4}

A system of p53 and NF- $\kappa$ B. A unified network of the $(\mathbf{A}) \mathrm{p} 53$ (red circles) and NF- $\mathrm{B}$ (yellow diamonds) networks, with their shared components clearly defined (in blue). (B) Condensed view of the two networks; and in (C) only the NF- $\kappa B$ network, which allows for a better visualisation of the connections. 
Table 8: Frequency and Biological process information on NF- $\mathrm{KB}$ and $\mathrm{p} 53$ networks connectors

\begin{tabular}{|c|c|c|c|c|}
\hline Connector protein & Frequency & Biological process involved & Protein in p53 & Protein in NF- $\kappa$ B. \\
\hline \multirow{2}{*}{$\begin{array}{l}\text { Heat shock protein HSP 90-beta } \\
\text { (HS90B_HUMAN) }\end{array}$} & 15 & & CD2A2_HUMAN & \\
\hline & & & P53_HUMAN & IKBB_HUMAN \\
\hline \multirow[t]{2}{*}{ Ubiquitin (UBIQ_HUMAN) } & 15 & $\begin{array}{l}\text { I3 processes]: APC-Cdc20 mediated degradation of } \\
\text { Nek2A; APC/C:Cdh I-mediated degradation of Skp2; } \\
\text { Apoptosis; Cdc20:Phospho-APC/C mediated } \\
\text { degradation of Cyclin A; Cell Cycle Checkpoints; Cell } \\
\text { Cycle, Mitotic; DNA Replication; HIV Infection; } \\
\text { Regulation of activated PAK-2p34 by proteasome } \\
\text { mediated degradation; Signalling by EGFR; Signalling by } \\
\text { Wnt; Signalling in Immune system; Signalling by NGF }\end{array}$ & MDM2_HUMAN & RELB_HUMAN \\
\hline & & & CDNIA_HUMAN & NFKB2_HUMAN \\
\hline \multirow{2}{*}{$\begin{array}{l}\text { Poly [ADP-ribose] polymerase I } \\
\text { (PARPI_HUMAN) }\end{array}$} & 10 & & CDNIA_HUMAN & NFKBI_HUMAN \\
\hline & & & P53_HUMAN & IKKB_HUMAN \\
\hline \multirow{2}{*}{$\begin{array}{l}\text { Stress-70 protein, mitochondrial } \\
\text { (GRP75_HUMAN) }\end{array}$} & 9 & & P53_HUMAN & REL_HUMAN \\
\hline & & & P53_HUMAN & NFKBI_HUMAN \\
\hline \multirow{2}{*}{$\begin{array}{l}\text { Heat shock cognate } 71 \text { kDa protein } \\
\text { (HSP7C_HUMAN) }\end{array}$} & 9 & Membrane Trafficking & P53_HUMAN & IKBE_HUMAN \\
\hline & & & P53_HUMAN & IKKE_HUMAN \\
\hline \multirow{2}{*}{$\begin{array}{l}\text { CREB-binding protein } \\
\text { (CBP_HUMAN) }\end{array}$} & 8 & Gene Expression & MDM2_HUMAN & IKKA_HUMAN \\
\hline & & & MDM2_HUMAN & IKKB_HUMAN \\
\hline \multirow{2}{*}{$\begin{array}{l}\text { Immunoglobulin heavy chain-binding } \\
\text { protein (GRP78_HUMAN) }\end{array}$} & 8 & Hemostasis & P53_HUMAN & NFKBI_HUMAN \\
\hline & & & P53_HUMAN & NFKB2_HUMAN \\
\hline \multirow{2}{*}{$\begin{array}{l}\text { Heat shock } 70 \mathrm{kDa} \text { protein IL } \\
\text { (HS7IL_HUMAN) }\end{array}$} & 8 & & P53_HUMAN & REL_HUMAN \\
\hline & & & P53_HUMAN & RELB_HUMAN \\
\hline \multirow{2}{*}{$\begin{array}{l}\text { Heat shock protein HSP 90-alpha } \\
\text { (HS90A_HUMAN) }\end{array}$} & 7 & & P53_HUMAN & IKBB_HUMAN \\
\hline & & & P53_HUMAN & IKBE_HUMAN \\
\hline \multirow{2}{*}{$\begin{array}{l}\text { Nuclear receptor subfamily } 3 \text { group } \\
\text { C member I (GCR_HUMAN) }\end{array}$} & 7 & Gene Expression & MDM2_HUMAN & NFKBI_HUMAN \\
\hline & & & MDM2_HUMAN & NFKB2_HUMAN \\
\hline
\end{tabular}

sible for inhibiting the NF- $\mathrm{B}$ inhibitory subunits with 324 interactions (see Table 5) [88]. A discovery that suggests IKKE_HUMAN to be the most studied protein of the NF- $\kappa \mathrm{B}$ system; and maybe a possible molecular target for therapy in the NF- $\kappa \mathrm{B}$ system. In addition to this, four other proteins were found to have interacting proteins numbering over 100. These were: TF65_HUMAN (RelA), NEMO_HUMAN (IKK $\gamma)$, NFKB2_HUMAN (p52), and NFKB1_HUMAN (p50) [Note - this finding could also be a reflection of the fact that these proteins may be the most studied members of the NF- $\kappa \mathrm{B}$ network]. For the cell cycle network, the highly connected nodes were four in number (see Figure 3C and Table 4). Compared to the NF- $\kappa B$ network (Figure 3B), the p53 (Figure 3A) and the cell cycle (Figure 3C) networks appeared to be sparse, with each node connected to a relatively small number of edges within the network, many of whom "know" each other. The sparse nature could be explained by the fact that only proteins involved in the oscillatory feedback loops of the systems of interest, and not the entire published members were considered in this study. The highest-degree node for the p53 network was the P53_HUMAN protein, and 
Table 9: Shortest paths

p53 network and cell cycle proteins

\begin{tabular}{|c|c|c|c|c|}
\hline & $\mathbf{R b}$ & E2F-I & $\mathbf{P 2 7}$ & Cyclin DI \\
\hline Direct link $(I=I)$ & 2 & 2 & 0 & 1 \\
\hline Path with $I=2$ & 44 & 17 & 31 & 25 \\
\hline Total shortest paths of all length $I(I=I, I=2, I=3, I=4, \ldots)$ & 46 & 19 & 31 & 26 \\
\hline
\end{tabular}

NF- $\kappa$ B network and cell cycle proteins

\begin{tabular}{|c|c|c|c|c|}
\hline & $\mathrm{Rb}$ & E2F-I & $\mathrm{P} 27$ & Cyclin DI \\
\hline Direct link $(I=1)$ & 0 & 1 & 0 & 0 \\
\hline Path with $I=2$ & 72 & 35 & 33 & 46 \\
\hline Total shortest paths of all length $I(I=I, I=2, I=3, I=4, \ldots)$ & 74 & 36 & 83 & 91 \\
\hline
\end{tabular}

Path lengths with $I=I$ is said to be a direct link. Total shortest path length is where $I=I, I=2, I=3$ and $I=4$

RB_HUMAN for the selected cell cycle proteins (both with degree connectivity value's, 300 and 156 respectively Table 5 and 6); a result signifying their importance in their various networks. Similarly, the vertex betweenness measure [80] also confirms IKKE_HUMAN, P53_HUMAN and RB_HUMAN as prominent nodes in their networks (Table 7) [see Additional file 1: Suppl. 11-13 for results obtained from other centrality measures]. In addition, various highly interconnected subgroups were also uncovered, namely: P53_HUMAN with MDM2_HUMAN; RELB_HUMAN with NFKB2_HUMAN; and E2F1_HUMAN with RB_HUMAN [see Additional file 1: Suppl. 1-3]. These subgroups could also be described as network motifs [89-91], frequently recurring groups of interactions, usually highly conserved, which are thought to perform specific information processing roles in the networks; in some cases supporting their roles as oscillators $[5,18,63,92]$.

Following the characterisation of the three networks with respect to their degree of connectivity, further calculations were made on their clustering coefficients. It was discovered that MDM2_HUMAN (mdm2) in the p53 network, REL_HUMAN (C-Rel) in the NF-kB network and E2F1_HUMAN (E2F-1) of the cell cycle were proteins found to have the highest clustering coefficient values; a finding reflecting on the nodes connectivity within their neighbourhood. That is to say, even though P53_HUMAN, RB_HUMAN and IKKE_HUMAN were found to be proteins with the most interaction within their individual networks; MDM2_HUMAN,
REL_HUMAN (C-Rel) and E2F1_HUMAN were revealed to be proteins best at forming cliques in their networks.

Having discovered for each system, the highly connected nodes, as well as the nodes with the most number of neighbours, it was of interest to study how all the individual system studied relates to each other. In order to do this, we set out to calculate the shortest paths and the frequency of proteins linking the systems to one another; thereby identifying key connector proteins thought to assist in the transmission of information (or cross talk) across the three networks. It was hoped that through this form of analysis, characteristics of the connector proteins linking the systems will be uncovered.

Network of interactions between $p 53$ and NF- $k B$ pathways Since it has been suggested that the topology of a network affects the spread of information carried by a signal and thus diseases [34], the network of interactions between the p53 and NF-кB systems were investigated. Figure 4 illustrates the complex network formed between the p53 and the NF- $\mathrm{BB}$ systems, and the connector proteins linking them (proteins in the p53 network are denoted in red, and those of the NF- $\mathrm{KB}$ are in yellow - Figure 4A). We found 365 paths connect proteins in the p53 network to proteins in the NF-кB network; among which, only two are direct connections and 295 require a connector protein. The two direct interactions were revealed to be between: P53_HUMAN and IKKA_HUMAN, and P53_HUMAN and IKBA_HUMAN proteins; illustrating potential connection route to consider when creating a 


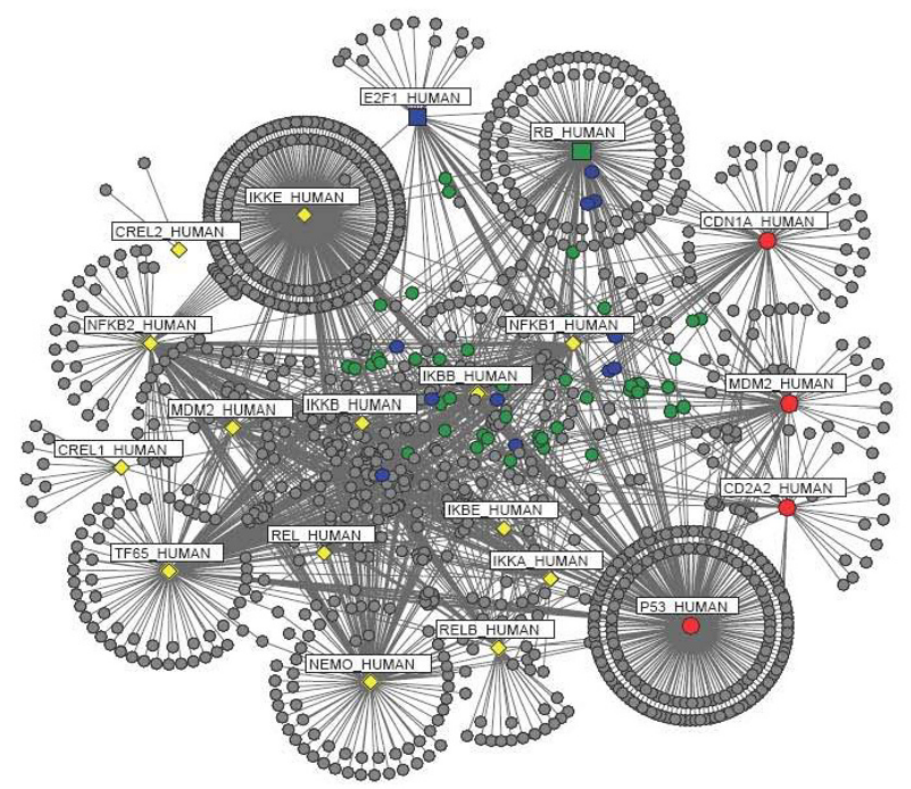

A

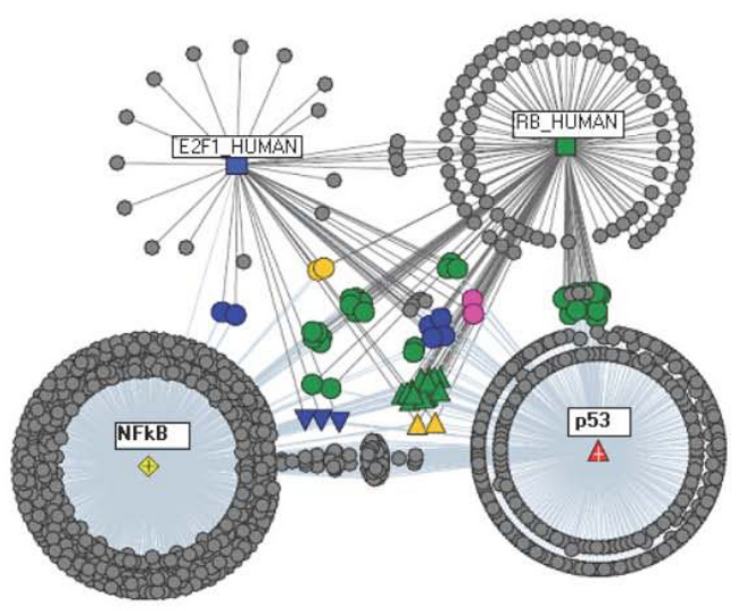

B

\section{Figure 5}

p53 and NF- $\kappa$ B with RB_HUMAN and E2FI_HUMAN. (A) Members of p53 (red circles) and NF- $\kappa B$ (yellow diamonds) networks, their connections with RB_HUMAN (green square) and E2FI_HUMAN (blue square\}) cell cycle proteins, and the common components shared between them. Components connecting RB_HUMAN with p53 and NF- $k B$ networks are denoted in green, whilst the components connecting E2FI_HUMAN with the two networks are denoted in blue. (B) A condensed view of only the $\mathrm{p} 53$ and NF- $\kappa$ B networks, and their interactions with RB_HUMAN and E2FI_HUMAN proteins. Triangular connector nodes represent common components between RB_HUMAN and the two networks (in green),

E2FI_HUMAN and the two networks (in blue), and RB_HUMAN and E2FI_HUMAN connections with the NF- $\kappa B$ and p53 networks (in yellow). Circular nodes in green denote RB_HUMAN connectors to p53 or NF- $\mathrm{kB}$ networks; and in blue for E2FI_HUMAN to $\mathrm{p} 53$ or NF- $\kappa B$ networks. The yellow and magenta circular nodes represent proteins connecting both E2FI_HUMAN and RB_HUMAN to members of the NF- $\kappa B$ (in yellow) and p53 (in magenta). Refer also to Tables $9,10,1 \mathrm{I}, \mathrm{I} 2$ and $\mathrm{I} 3$ for further information. 


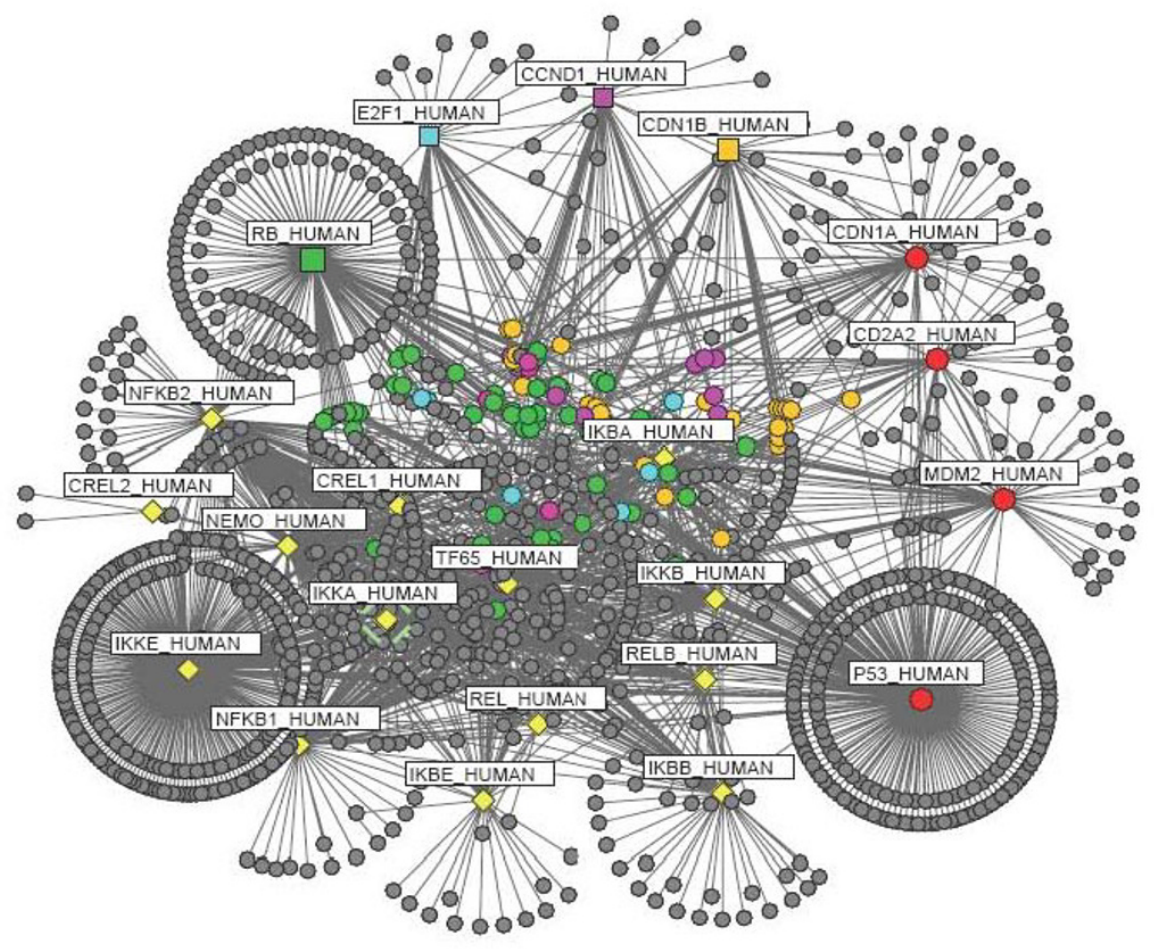

A

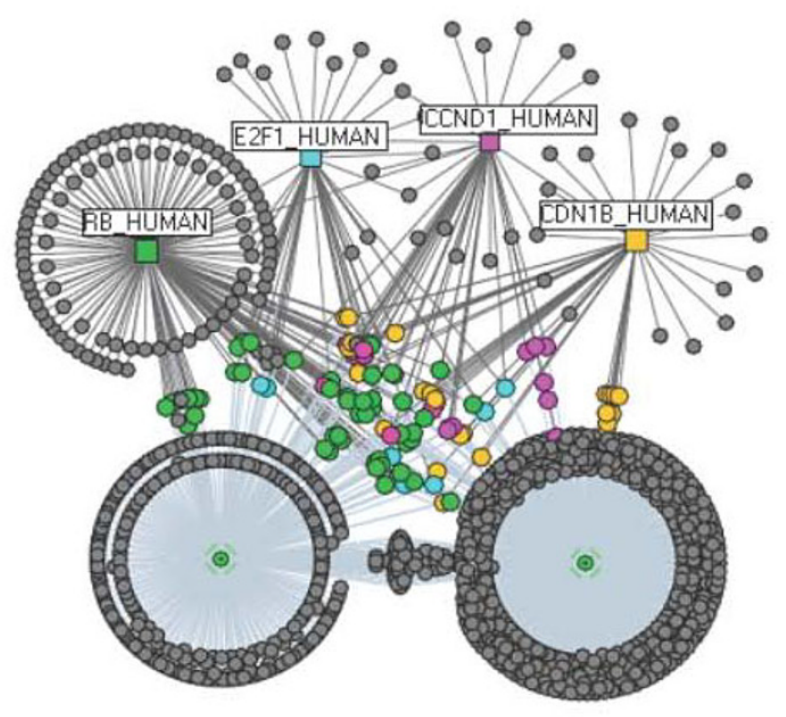

B

Figure 6

Network representation of $\mathrm{p53}, \mathrm{NF}-\kappa \mathrm{B}$ and cell cycle interactions. (A) Network topology of the combined networks of the p53 (red), NF-אB (yellow) and the cell cycle \{CDNIB_HUMAN (orange), CCNDI_HUMAN (magenta), RB_HUMAN (green), E2FI_HUMAN (blue)\}. Connector nodes linking cell cycle proteins to either NF- $\kappa \mathrm{B}$ or $\mathrm{p} 53$; or to both have been denoted according to the colour of the cell cycle protein counterpart. For example, since E2FI_HUMAN is denoted in blue, connector proteins linking it to the $\mathrm{p} 53$ or NF- $\mathrm{KB}$, or to both will be highlighted in blue (B) Condensed view of the $\mathrm{p} 53$ and NF- $\kappa B$ networks, and their connections with cell cycle proteins. The connectors have been labelled according to (A). 
Table 10: Frequent components linking E2FI_HUMAN to NF- $\kappa B$ pathway

\begin{tabular}{llll}
\hline Connector protein & Frequency & Protein in NF- $\kappa$ B & Additional information of connector proteins \\
\hline NFKBI_HUMAN & 9 & IKBA_HUMAN & Nuclear factor NF-kappa-B pI05 subunit \\
PARPI_HUMAN & 4 & NFKB2_HUMAN & Poly [ADP-ribose] polymerase I \\
NCOA3_HUMAN & 3 & IKKA_HUMAN & Nuclear receptor coactivator 3 \\
CULI_HUMAN & 3 & IKBB_HUMAN & Cullin-I \\
CBP_HUMAN & 3 & TF65_HUMAN & CREB-binding protein \\
SPI_HUMAN & 2 & (Involved in Gene Expression process) \\
P53_HUMAN & & REL_HUMAN & Transcription factor SpI \\
TIP60_HUMAN & 2 & IKKA_HUMAN & Cellular tumor antigen p53 \\
PHB_HUMAN & I & CRELI_HUMAN & Histone acetyltransferase HTATIP \\
PA2G4_HUMAN & I & TF65_HUMAN & Prohibitin \\
& IKKE_HUMAN & Proliferation-associated protein 2G4 \\
\hline
\end{tabular}

unified model of the NF- $\mathrm{KB}$ and $\mathrm{p} 53$ system. Indirect links for the rest of the nodes were found to require protein mediators to act as connector proteins. The proteins acting as connectors between the two networks are shown in blue in Figure $4 \mathrm{~A}, \mathrm{~B}$ and $4 \mathrm{C}$. It is evident that the P53_HUMAN protein can itself act as a connecting protein between members of the NF-kB pathway and members of the p53 system (for example, CDN1A_HUMAN P53_HUMAN - IKKA_HUMAN; and, MDM2_HUMAN P53_HUMAN - IKKA_HUMAN).

After having determined the shortest paths linking the p53 and NF- $\mathrm{kB}$ systems, the identified connector proteins linking the two systems were grouped according to their frequency values, and cross referenced with reference databases, for the interpretation of their functional prop- erties. Table 8 provides a list of the top ten connecting nodes with the most number of paths passing through it [see Additional file 1: Suppl. 14-18 for further information extracted for these proteins]. It shows the frequency values for the connector protein with shortest paths $l=2$, and the biological processes associated with the connector protein. Members of the NF- $\mathrm{kB}$ and p53 network sharing the same connector protein are also listed in Table 8 (Note, only two examples for each connection with the same frequency values have been presented). Interestingly, Heat shock protein HSP 90-beta (HS90B_HUMAN) and Ubiquitin (UBIQ_HUMAN) were revealed to be important proteins with the highest frequency, $f=15$, linking proteins in the 553 system to proteins in the NF$\kappa B$ system. Two examples of each connection are: CD2A2_HUMAN - HS90B_HUMAN - TF65_HUMAN;

Table I I: Frequent components linking RB_HUMANto NF-KB pathway

\begin{tabular}{|c|c|c|c|}
\hline Connector protein & Frequency & Protein in NF- $\kappa$ B & Additional information of connector proteins \\
\hline HSP7C_HUMAN & 10 & IKKB_HUMAN & $\begin{array}{l}\text { Heat shock cognate 7I kDa protein } \\
\text { (Involved in Membrane Trafficking process) }\end{array}$ \\
\hline HDAC2_HUMAN & 4 & NFKBI_HUMAN & $\begin{array}{l}\text { Histone deacetylase } 2 \\
\text { (Involved in } 2 \text { processes: Gene Expression; Signalling by NGF) }\end{array}$ \\
\hline ESRI_HUMAN & 3 & IKKB_HUMAN & Estrogen receptor \\
\hline HDACI_HUMAN & 3 & IKKA_HUMAN & $\begin{array}{l}\text { Histone deacetylase I } \\
\text { (Involved in } 2 \text { processes: Gene Expression; Signalling by NGF) }\end{array}$ \\
\hline SMCA4_HUMAN & 3 & RELB_HUMAN & Probable global transcription activator SNF2L4 \\
\hline TBP_HUMAN & 3 & NFKB2_HUMAN & $\begin{array}{l}\text { TATA-box-binding protein } \\
\text { (Involved in } 3 \text { processes: Gene Expression; HIV Infection; Transcription) }\end{array}$ \\
\hline BRCAI_HUMAN & 2 & TF65_HUMAN & $\begin{array}{l}\text { Breast cancer type I susceptibility protein } \\
\text { (Involved in DNA Repair process) }\end{array}$ \\
\hline ANDR_HUMAN & 2 & TF65_HUMAN & Androgen receptor \\
\hline CEBPB_HUMAN & 2 & NFKBI_HUMAN & CCAAT/enhancer-binding protein beta \\
\hline CDK9_HUMAN & 2 & TF65_HUMAN & $\begin{array}{l}\text { Cell division protein kinase } 9 \\
\text { (Involved in } 9 \text { processes: Elongation arrest and recovery; Gene Expression; HIV } \\
\text { Infection; HIV-I elongation arrest and recovery; Pausing and recovery of HIV-I } \\
\text { elongation; Pausing and recovery of Tat-mediated HIV-I elongation; Pausing and } \\
\text { recovery of elongation; Tat-mediated HIV-I elongation arrest and recovery; } \\
\text { Transcription) }\end{array}$ \\
\hline
\end{tabular}


Table I2: Frequent components linking E2F I_HUMAN to the p53 network

\begin{tabular}{|c|c|c|c|}
\hline Connector protein & Frequency & Protein in p53 & Additional information of connector proteins \\
\hline P53_HUMAN & 2 & CDNIA_HUMAN & Cellular tumor antigen p53 \\
\hline CBP_HUMAN & 2 & MDM2_HUMAN & CREB-binding protein \\
\hline RB_HUMAN & 2 & CDNIA_HUMAN & Retinoblastoma-associated protein \\
\hline TIP60_HUMAN & 1 & MDM2_HUMAN & Histone acetyltransferase HTATIP \\
\hline SKP2_HUMAN & I & CDNIA_HUMAN & S-phase kinase-associated protein 2 \\
\hline PARPI_HUMAN & I & CDNIA_HUMAN & Poly [ADP-ribose] polymerase I \\
\hline ATM_HUMAN & 1 & MDM2_HUMAN & $\begin{array}{l}\text { Serine-protein kinase ATM } \\
\text { (Involved in } 2 \text { processes: Cell Cycle Checkpoints; DNA Repair) }\end{array}$ \\
\hline MDM4_HUMAN & I & MDM2_HUMAN & Protein Mdm4 \\
\hline CHK2_HUMAN & 1 & MDM2_HUMAN & $\begin{array}{l}\text { Serine/threonine-protein kinase Chk2 } \\
\text { (Involved in } 3 \text { processes: Cdc20:Phospho-APC/C mediated degradation of Cyclin A; } \\
\text { Cell Cycle) }\end{array}$ \\
\hline CDK3_HUMAN & 1 & CDNIA_HUMAN & Cell division protein kinase 3 \\
\hline
\end{tabular}

and P53_HUMAN - HS90B_HUMAN - IKBB_HUMAN for HSP 90-beta; and MDM2_HUMAN - UBIQ_HUMAN RELB_HUMAN; and CDN1A_HUMAN - UBIQ_HUMAN - NFKB2_HUMAN for Ubiquitin. The frequency results were useful in establishing the importance of shared proteins between systems.

\section{Network of interactions between $p 53, N F-\kappa B$ and the GII $S$ phase of the Cell cycle}

Since it has been suggested, that some cell cycle proteins are activated by one pathway and are relevant for the regulation of another [44,65-69], it was of interest to investigate the relationship between the NF- $\kappa \mathrm{B}, \mathrm{p} 53$ and the cell cycle systems. For this study, only events leading to the $\mathrm{G} 1 / \mathrm{S}$ transition phase of the cell cycle, the point where NF- $\kappa \mathrm{B}$ and p53 signal transduction events are active the most [93] were considered. We start by exploring the interactions between RB_HUMAN and E2F1_HUMAN cell cycle proteins, with members of the p53 and NF- $\kappa \mathrm{B}$ networks. Figure 5 show the network obtained from this analysis. Proteins that link the proteins in the p53 and NF- $\kappa \mathrm{B}$ networks to $\mathrm{RB} \_$HUMAN are denoted in green, whilst the proteins connecting the two networks to E2F1_HUMAN are in blue (Figure 5A). Common protein shared between the $\mathrm{p} 53$ and NF- $\mathrm{B}$ networks have been represented in the form of green triangles (for links to RB_HUMAN) and blue triangles (for links with E2F1_HUMAN) (see Figure 5B). Closer evaluation of the interactions linking the p53 network to the cell cycle proteins (Table 9), identified 46 shortest paths for interactions with RB_HUMAN (44 of which are indirect links mediated by a single node and 2 direct links \{CDN1A_HUMAN - RB_HUMAN [66,94]; MDM2_HUMAN - RB_HUMAN \}); and 19 shortest paths for interactions with E2F1_HUMAN (17 of which are indirect links mediated by a single node, and 2 direct links \{CD2A2_HUMAN - E2F1_HUMAN; P53_HUMAN E2F1_HUMAN \}). These results therefore suggest an active role of CDN1A_HUMAN (p21) and MDM2_HUMAN (mdm2) on the activity of the RB_HUMAN protein in the cell cycle. And thus implies possible connection routes to consider when constructing

Table 13: Frequent components linking RB_HUMAN to the p53 network

\begin{tabular}{|c|c|c|c|}
\hline Connector protein & Frequency & Protein in p53 & Additional information of connector proteins \\
\hline P53_HUMAN & 2 & CDNIA_HUMAN & Cellular tumor antigen $\mathrm{p} 53$ \\
\hline CBP_HUMAN & 2 & MDM2_HUMAN & CREB-binding protein \\
\hline RB_HUMAN & 2 & CDNIA_HUMAN & Retinoblastoma-associated protein \\
\hline TIP60_HUMAN & 1 & MDM2_HUMAN & Histone acetyltransferase HTATIP \\
\hline SKP2_HUMAN & I & CDNIA_HUMAN & S-phase kinase-associated protein 2 \\
\hline PARPI_HUMAN & 1 & CDNIA_HUMAN & Poly [ADP-ribose] polymerase I \\
\hline ATM_HUMAN & 1 & MDM2_HUMAN & $\begin{array}{l}\text { Serine-protein kinase ATM } \\
\text { (Involved in } 2 \text { processes: Cell Cycle Checkpoints; DNA Repair) }\end{array}$ \\
\hline MDM4_HUMAN & 1 & MDM2_HUMAN & Protein Mdm4 \\
\hline CHK2_HUMAN & 1 & MDM2_HUMAN & $\begin{array}{l}\text { Serine/threonine-protein kinase Chk2 } \\
\text { (Involved in } 3 \text { processes: Cdc20:Phospho-APC/C mediated degradation of Cyclin A; } \\
\text { Cell Cycle) }\end{array}$ \\
\hline CDK3_HUMAN & 1 & CDNIA_HUMAN & Cell division protein kinase 3 \\
\hline
\end{tabular}


a unified model of the p53 and the G1/S phase of the cell cycle networks. Likewise, for the NF- $\kappa \mathrm{B}$ network, 74 shortest paths were identified linking $N F-\kappa B$ proteins to RB_HUMAN (all of which were indirect links); and 36 shortest paths for interactions with E2F1_HUMAN (of which only a single direct link was observed, IKBA_HUMAN - E2F1_HUMAN).

We repeated this analysis to include interactions between the rest of the G1/S cell cycle proteins (RB_HUMAN, CCND1_HUMAN, CDN1B_HUMAN, and E2F1_HUMAN) and the members of the p53 and NF- $\mathrm{B}$ networks (see Figure 6 - only the connecting nodes linking CDN1B_HUMAN (p27, circle, yellow), CCND1_HUMAN (Cyclin D1, circle, magenta), RB_HUMAN (Rb, circle, green) and E2F1_HUMAN (E2F-1, circle, blue) to the p53 and NF$\kappa \mathrm{B}$ networks have been colour coded - Figure 6A and $6 \mathrm{~B}$ ). Shortest path lengths calculated for interactions between proteins in the p53 network and CDN1B_HUMAN, numbered 31 (all indirect links with path length $=2$ ); and 26 for interactions with CCND1_HUMAN (25 indirect connection with path length $=2$ and 1 direct connection \{CDN1A_HUMAN - CCND1_HUMAN\}). Similarly, for the NF- $\mathrm{B}$ system, 83 shortest paths connecting CDN1B_HUMAN (33 of which have path length = 2), and 91 shortest paths connecting CCND1_HUMAN(46 of which are indirect links mediated by a single connector path length $=2$ ) to members of the NF- $\mathrm{B}$ network were determined (see Table 9 for shortest paths statistics). Frequency values and functional properties ascertained for nodes linking the p53 and cell cycle networks, as well for those linking the NF- $\kappa \mathrm{B}$ with the cell cycle network have been reviewed in Table 10, 11, 12 and 13 [see Additional file 1: Suppl. 19-24 for a full list].

\section{Conclusion}

A network is usually thought of as a coherent system that comprises of units interacting in some kind of orchestrated and regulated fashion - such that the emergent behaviour of the whole (i.e. the network) is recognisable and can be characterised. Once some of the behaviour is recognised, the system can be described at a level of detail appropriate to the system's behaviour whilst ignoring the details of the constituent parts. Since molecular networks are large and complex, with their components and their interactions quite heterogeneous characterising the relationship between structure and dynamics of the system makes it far from straightforward. Although research aiming at coping with these challenges has become very popular, it is important to bear in mind that the current efforts can only profit from a combined theoretical and experimental approach. This is where the approach presented in this paper becomes beneficial. The idea is that by combining both the data driven and knowledge driven strategies, direct and or combinatorial interaction parameters of many protein can be captured from the information gained, and can thus be used to construct, guide and or unify dynamical models of signal transduction pathways from which a realistic model of the systems behaviour can be determined. The resulting dynamical model can then provide the conceptual and explanatory linkage between the observed phenomena and the predicted.

This framework of computational modelling of molecular networks at various levels or organisation has the potential to allow cost effective experimentation and hypothesis exploration, computationally uncovering the behaviour of molecular species and combinatorial interactions that would be difficult and too expensive to carry out in a wetlab setting. While, network topology analysis is thus useful for showing which proteins in the network depend on which other protein, it does not give us any further information on the regulatory effects of these dependencies. Despite these methodological limitations, our results offer a view, demonstrating the importance of elucidating the functional roles key or shared components play in the propagation of signals across transduction systems.

The main implication of the presented application is the recognition that changes in one signalling system, undoubtedly causes a ripple effect on the rest of the surrounding system - as shown by the extensive interconnection of the systems studied and their common shared components. It is hoped that the use of this form of analysis may also be beneficial in highlighting areas of research where very little is known for further future study.

\section{Authors' contributions}

AECI conceived the project and design. AECI and TPN prepared the data. TPN extracted processed data from public databases, implemented the algorithms and analysed the results. AECI and TPN wrote the paper. All authors read and approved the document.

\section{Additional material}

\section{Additional file 1}

Supplementary Material. The data provided correspond to supplementary calculation details, as well as additional information on the topological and functional properties of the p53, NF- $\kappa B$ and cell cycle networks. All proteins are listed according to their Uniprot accession number and protein ID name.

Click here for file

[http://www.biomedcentral.com/content/supplementary/14712105-10-370-S1.zip]

\section{Acknowledgements}

This project has been partially funded by FIRB Project RBPR0523C3. The authors wish to thank colleagues at CoSBi: Ferenc Jordán, Sean Sedwards, 
Matteo Cavaliere and Ivan Mura for valuable discussions and editorial suggestions.

\section{References}

I. Everitt BS: Cluster Analysis. London: Edward Arnold; 1993.

2. Alberts B, Bray D, Lewis J, Raff M, Roberts K: Molecular biology of the cell. 4th edition. Garland publishing; 2002

3. Nicolau M, Tibshirani R, Borresen-Dale AL, Jeffrey SS: Disease-specific genomic analysis: identifying the signature of pathologic biology. Bioinformatics 2007, 23(8):957-965.

4. Goldbeter A: Computational approaches to cellular rhythms. Nature 2002, 420(69 I 2):238-245

5. Nelson DE, Ihekwaba AE, Elliott M, Johnson JR, Gibney CA, Foreman BE, Nelson G, See V, Horton CA, Spiller DG, et al.: Oscillations in NF-kappaB signaling control the dynamics of gene expression. Science 2004, 306(5696):704-708

6. Goldbeter A: A model for circadian oscillations in the Drosophila period protein (PER). Proc R Soc Lond B Biol Sci 1995 , 26I(1362):319-324

7. Gagneur J, Casari G: From molecular networks to qualitative cell behavior. FEBS Lett 2005, 579(8):|867-|87|.

8. Gagneur J, Krause R, Bouwmeester T, Casari G: Modular decomposition of protein-protein interaction networks. Genome Biol 2004, 5(8):R57.

9. Bhalla US: Understanding complex signaling networks through models and metaphors. Prog Biophys Mol Biol 2003, 8 I(I):45-65

10. Kell DB: Metabolomics, machine learning and modelling: towards an understanding of the language of cells. Biochem Soc Trans 2005, 33(Pt 3):520-524.

I I. Yaffe MB: Signaling networks and mathematics. Sci Signal 2008, I (43):eg7.

12. Barabasi AL, Albert R: Emergence of scaling in random networks. Science 1999, 286(5439):509-5I2.

13. Barabasi AL, Oltvai ZN: Network biology: understanding the cell's functional organization. Nat Rev Genet 2004, 5(2): I 0 I - I I 3.

14. Strogatz SH: Exploring complex networks. Nature 200I, 4I0(6825):268-276

15. Watts DJ, Strogatz SH: Collective dynamics of 'small-world' networks. Nature 1998, 393(6684):440-442.

16. Hoffmann A, Levchenko A, Scott ML, Baltimore D: The IkappaBNF-kappaB signaling module: temporal control and selective gene activation. Science 2002, 298(5596): $|24|-\mid 245$

17. Ma L, Wagner J, Rice J], Hu W, Levine AJ, Stolovitzky GA: A plausible model for the digital response of p53 to DNA damage. Proc Natl Acad Sci USA 2005, I 02(40): | 4266-|427|

18. Lahav G, Rosenfeld N, Sigal A, Geva-Zatorsky N, Levine AJ, Elowitz $\mathrm{MB}$, Alon U: Dynamics of the p53-Mdm2 feedback loop in individual cells. Nat Genet 2004, 36(2): | 47-150.

19. Ihekwaba AE, Wilkinson SJ, Waithe D, Broomhead DS, Li P, Grimley $\mathrm{RL}$, Benson N: Bridging the gap between in silico and cellbased analysis of the nuclear factor-kappaB signaling pathway by in vitro studies of IKK2. Febs J 2007, 274(7): I678- I690.

20. Bairoch A, Apweiler R, Wu CH, Barker WC, Boeckmann B, Ferro S Gasteiger E, Huang H, Lopez R, Magrane M, et al:: The Universal Protein Resource (UniProt). Nucleic Acids Research 2005, 33:DI54-DI59.

21. Brown KR, Jurisica I: Unequal evolutionary conservation of human protein interactions in interologous networks. Genome Biology 2007, 8(5):R95.

22. Joshi-Tope G, Gillespie M, Vastrik I, D'Eustachio P, Schmidt E, de Bono B, Jassal B, Gopinath GR, Wu GR, Matthews L, et al.: Reactome: a knowledgebase of biological pathways. Nucl Acids Res 2005, 33(suppl I):428-432

23. Schaefer CF, Anthony K, Krupa S, Buchoff J, Day M, Hannay T, Buetow KH: PID: the Pathway Interaction Database. Nucl Acids Res 2009, 37(suppl_I):D674-679.

24. Priami C, Ballarini P, Qualia P: BlenX4Bio: BlenX for biologists. In Proc 7th International Conference on Computational Methods in Systems Biology: 2009 Bologna: Springer; 2009.

25. Dematte L, Priami C, Romanel A: The Beta Workbench: a computational tool to study the dynamics of biological systems. Brief Bioinform 2008, 9(5):437-449.

26. Schlitt T, Brazma A: Current approaches to gene regulatory network modelling. BMC Bioinformatics 2007, 8(Suppl 6):S9.
27. Schlitt T, Palin K, Rung J, Dietmann S, Lappe M, Ukkonen E, Brazma A: From gene networks to gene function. Genome Res 2003, I 3( I 2):2568-2576

28. Priami C: Algorithmic Systems Biology. An opportunity for computer science. Communications of the ACM 2009, 52(5):80-88.

29. Han J, Kamber M: Data Mining: Concepts and Techniques (The Morgan Kaufmann Series in Data Management Systems). San Francisco: Morgan Kaufmann; 2000.

30. Wang JTL, Zaki MJ, Toivonen HTT, Shasha DE: Data Mining in Bioinformatics. London: Springer; 2005.

31. Bhaskar H, Hoyle DC, Singh S: Machine learning in bioinformatics: A brief survey and recommendations for practitioners. Intelligent Technologies in Medicine and Bioinformatics 2006 , 36( I 0): I I04-I I 25

32. Larranaga P, Calvo B, Santana R, Bielza C, Galdiano J, Inza I, Lozano JA, Armananzas R, Santafe G, Perez A, et al.: Machine learning in bioinformatics. Brief Bioinform 2006, 7(I):86-II2.

33. Jang H, Lim J, Lim J-H, Park S-J, Lee K-C, Park S-H: Finding the evidence for protein-protein interactions from PubMed abstracts. Bioinformatics 2006, 22( I4):e220-226.

34. Lee DS, Park J, Kay KA, Christakis NA, Oltvai ZN, Barabasi AL: The implications of human metabolic network topology for disease comorbidity. Proc Natl Acad Sci USA 2008 I 05(29): $9880-9885$.

35. Brazhnik P, de la Fuente A, Mendes P: Gene networks: how to put the function in genomics. Trends Biotechnol 2002 20( I I ):467-472.

36. Lecca P, Palmisano A, Ihekwaba A, Priami C: Calibration of dynamic models of biological systems with KInfer. Eur Biophys J 2009.

37. Baud V, Karin M: Is NF-kappaB a good target for cancer therapy? Hopes and pitfalls. Nat Rev Drug Discov 2009, 8(I):33-40.

38. Ghosh S, May MJ, Kopp EB: NF-kappa B and Rel proteins: evolutionarily conserved mediators of immune responses. Annu Rev Immunol 1998, 1 6:225-260.

39. Ihekwaba AEC, Broomhead DS, Grimley R, Benson N, White MRH, Kell DB: Synergistic control of oscillations in the NF-kappaB signalling pathway. IEE Systems Biology 2005, I 52(3): I 53- I60.

40. Ihekwaba AEC, Broomhead DS, Grimley RL, Benson N, Kell DB: Sensitivity analysis of parameters controlling oscillatory signalling in the NF- $\kappa \mathbf{B}$ pathway: the roles of IKK and $I_{\kappa} \mathbf{B} \alpha$. Systems Biology 2004, I(I):93-I03.

4I. Araki K, Kawauchi K, Tanaka N: IKK/NF-kappaB signaling pathway inhibits cell-cycle progression by a novel Rb-independent suppression system for E2F transcription factors. Oncogene 2008, 27(43):5696-5705

42. Kawauchi K, Araki K, Tobiume K, Tanaka N: Activated p53 induces NF-kappaB DNA binding but suppresses its transcriptional activation. Biochem Biophys Res Commun 2008, 372(I):|37-|4|.

43. Kawauchi $\mathrm{K}$, Araki $\mathrm{K}$, Tobiume $\mathrm{K}$, Tanaka $\mathrm{N}$ : p53 regulates glucose metabolism through an IKK-NF-kappaB pathway and inhibits cell transformation. Nat Cell Biol 2008, I0(5):6 I I-6I8.

44. Webster GA, Perkins ND: Transcriptional cross talk between NF-kappaB and p53. Mol Cell Biol 1999, I 9(5):3485-3495.

45. Pigolotti S, Krishna S, Jensen $\mathrm{MH}$ : Oscillation patterns in negative feedback loops. Proc Natl Acad Sci USA 2007, I 04( I 6):6533-6537.

46. Schumm K, Rocha S, Caamano J, Perkins ND: Regulation of p53 tumour suppressor target gene expression by the p52 NF. kappaB subunit. Embo J 2006, 25(20):4820-4832.

47. Tergaonkar V, Bottero V, Ikawa M, Li Q, Verma IM: IkappaB kinaseindependent IkappaBalpha degradation pathway: functional NF-kappaB activity and implications for cancer therapy. Mol Cell Biol 2003, 23(22):8070-8083.

48. Tergaonkar V, Pando M, Vafa O, Wahl G, Verma I: p53 stabilization is decreased upon NFkappaB activation: a role for NFkappaB in acquisition of resistance to chemotherapy. Cancer Cell 2002, I (5):493-503.

49. Tergaonkar V, Perkins ND: p53 and NF-kappaB crosstalk: IKKaIpha tips the balance. Mol Cell 2007, 26(2): I58-I59.

50. Trimarchi JM, Lees JA: Sibling rivalry in the E2F family. Nat Rev Mol Cell Biol 2002, 3(I): I I-20.

51. Frolov MV, Dyson NJ: Molecular mechanisms of E2F-dependent activation and pRB-mediated repression. J Cell Sci 2004, I I (Pt I I):2|73-2|8| 
52. Frolov MV, Huen DS, Stevaux O, Dimova D, Balczarek-Strang K, Elsdon M, Dyson NJ: Functional antagonism between E2F family members. Genes Dev 200I, I5(I 6):2I46-2I 60.

53. Lim CA, Yao F, Wong J], George J, Xu H, Chiu KP, Sung WK, Lipovich L, Vega VB, Chen J, et al.: Genome-wide mapping of RELA(p65) binding identifies E2FI as a transcriptional activator recruited by NF-kappaB upon TLR4 activation. Mol Cell 2007. 27(4):622-635.

54. Phillips AC, Ernst MK, Bates S, Rice NR, Vousden KH: E2F-I potentiates cell death by blocking antiapoptotic signaling pathways. Mol Cell I999, 4(5):77I-78I

55. Hitchens MR, Robbins PD: The role of the transcription factor DP in apoptosis. Apoptosis 2003, 8(5):46 I-468.

56. Baguley $\mathrm{BC}$, Marshall E: Do negative feedback oscillations drive variations in the length of the tumor cell division cycle? Oncol Res 2005, I 5(6):29|-294.

57. Barre B, Perkins ND: A cell cycle regulatory network controlling NF-kappaB subunit activity and function. Embo J 2007 26(23):484|-4855.

58. Perkins ND: Integrating cell-signalling pathways with NF-kappaB and IKK function. Nat Rev Mol Cell Biol 2007, 8(I):49-62.

59. Campbell KJ, Perkins ND: Regulation of NF-kappaB function. Biochem Soc Symp 2006: I65-180.

60. Vousden $\mathrm{KH}$ : Outcomes of p53 activation--spoilt for choice. Cell Sci 2006, I I 9(Pt 24):50 I5-5020.

61. Phillips AC, Vousden KH: E2F-I induced apoptosis. Apoptosis 200।, 6(3): I73-182.

62. Lahav G: The strength of indecisiveness: oscillatory behavior for better cell fate determination. SCi STKE 2004 2004(264):pe55.

63. Calzone L, Gelay A, Zinovyev A, Radvanyi F, Barillot E: A comprehensive modular map of molecular interactions in RB/E2F pathway. Mol Syst Biol 2008, 4: 173.

64. Novak B, Tyson Jl, Gyorffy B, Csikasz-Nagy A: Irreversible cellcycle transitions are due to systems-level feedback. Nat Cell Biol 2007, 9(7):724-728.

65. Dotto GP: p2I(WAFI/CipI): more than a break to the cell cycle? Biochim Biophys Acta 2000, I 47I(I):M43-56.

66. Sheahan S, Bellamy CO, Treanor L, Harrison DJ, Prost S: Additive effect of p53, p2 I and Rb deletion in triple knockout primary hepatocytes. Oncogene 2004, 23(8): | 489-| 497.

67. Kamijo T, Weber JD, Zambetti G, Zindy F, Roussel MF, Sherr C) Functional and physical interactions of the ARF tumor suppressor with p53 and Mdm2. Proc Natl Acad Sci USA 1998 95( I 4):8292-8297.

68. Pomerantz J, Schreiber-Agus N, Liegeois NJ, Silverman A, Alland L, Chin L, Potes J, Chen K, Orlow I, Lee HW, et al.: The Ink4a tumor suppressor gene product, p I9Arf, interacts with MDM2 and neutralizes MDM2's inhibition of p53. Cell I998, 92(6):713-723.

69. Stott FJ, Bates S, James MC, McConnell BB, Starborg M, Brookes S, Palmero I, Ryan K, Hara E, Vousden $\mathrm{KH}$, et al:: The alternative product from the human CDKN2A locus, p I 4(ARF), participates in a regulatory feedback loop with p53 and MDM2. Embo J 1998, I 7(I 7):500 I-50I4.

70. Joyce D, Albanese C, Steer J, Fu M, Bouzahzah B, Pestell RG: NF-kap$\mathrm{paB}$ and cell-cycle regulation: the cyclin connection. Cytokine Growth Factor Rev 200I, I 2(I):73-90.

7I. Steffen M, Petti A, Aach J, D'haeseleer P, Church G: Automated modelling of signal transduction networks. BMC Bioinformatics 2002, 3(34):

72. Allen EE, Fetrow JS, Daniel LW, Thomas SJ, John DJ: Algebraic dependency models of protein signal transduction networks from time-series data. Journal of Theoretical Biology 2006 238(2):317-330.

73. $\mathrm{Ng} \mathrm{SK}$, Tan SH: Discovering protein-protein interactions. Journal of Bioinformatics and Computational Biology 2003, I (4):7| I-74 I.

74. Jennifer AM, Dahesh S, Haynes ], Andrews B], Davidson AR: Proteinprotein interaction affinity plays a crucial role in controlling the Sholp-mediated signal transduction pathway in Yeast. Mol Cell 2004, I 4:8I3-823.

75. Jeong $H$, Tombor $B$, Albert R, Oltvai ZN, Barabasi AL: The largescale organization of metabolic networks. Nature 2000 407(6804):65I-654

76. Kim BJ, Yoon CN, Han SK, Jeong $\mathrm{H}$ : Path finding strategies in scale-free networks. Phys Rev E Stat Nonlin Soft Matter Phys 2002, 65(2 Pt 2):027103.
77. Spirin V, Mirny LA: Protein complexes and functional modules in molecular networks. Proc Natl Acad Sci USA 2003, I00(2I): I $2123-12128$.

78. Lin C, Cho Y, Hwang W, Pei P, Zhang A: Clustering Methods In Protein-Protein Interaction Network. In Knowledge Discovery in Bioinformatics: Techniques, Methods and Application Edited by: Xiaohua H, Yi P. Hoboken, NJ: Wiley InterScience; 2006:319-355.

79. Yu H, Kim PM, Sprecher E, Trifonov V, Gerstein M: The importance of bottlenecks in protein networks: correlation with gene essentiality and expression dynamics. PLoS Comput Biol 2007, 3(4):e59.

80. Zhang $S$, Jin $G$, Zhang XS, Chen L: Discovering functions and revealing mechanisms at molecular level from biological networks. Proteomics 2007, 7( I 6):2856-2869.

81. Zotenko E, Mestre J, O'Leary DP, Przytycka TM: Why do hubs in the yeast protein interaction network tend to be essential: reexamining the connection between the network topology and essentiality. PLoS Comput Biol 2008, 4(8):e I000I 40.

82. Cormen TH, Leiserson CE, Rivest RL, Stein C: Introduction to Algorithms. Second edition. Cambridge, MA: The MIT Press; 200 I.

83. Knuth DE: Art of Computer Programming, Fundamental Algorithms. Volume I. 3rd edition. Reading, MA: Addison-Wesley Professional; 1997.

84. Freeman LC: A set of measures of centrality based on betweenness. Sociometry 1977, 40(I):35-37.

85. Schlitt T, Brazma A: Modelling in molecular biology: describing transcription regulatory networks at different scales. Philos Trans R Soc Lond B Biol Sci 2006, 36 I ( I 467):483-494.

86. Chartrand G: Introductory Graph Theory. New York: Dover: 1985

87. Harary F: Graph Theory. Reading MA: Addison-Wesley; 1994.

88. Chariot A, Leonardi A, Muller J, Bonif M, Brown K, Siebenlist U: Association of the adaptor TANK with the I kappa B kinase (IKK) regulator NEMO connects IKK complexes with IKK epsilon and TBKI kinases. J Biol Chem 2002 , 277(40):37029-37036

89. Alon U: Network motifs: theory and experimental approaches. Nat Rev Genet 2007, 8(6):450-46I

90. Milo R, Shen-Orr S, Itzkovitz S, Kashtan N, Chklovskii D, Alon U: Network motifs: simple building blocks of complex networks. Science 2002, 298(5594):824-827.

91. Kashtan N, Itzkovitz S, Milo R, Alon U: Topological generalizations of network motifs. Phys Rev E Stat Nonlin Soft Matter Phys 2004, 70(3 Pt I):031909.

92. Geva-Zatorsky N, Rosenfeld N, Itzkovitz S, Milo R, Sigal A, Dekel E, Yarnitzky T, Liron Y, Polak P, Lahav G, et al.: Oscillations and variability in the p53 system. Mol Syst Biol 2006, 2:2006 0033.

93. Kaltschmidt B, Kaltschmidt C, Hehner SP, Droge W, Schmitz ML: Repression of NF-kappaB impairs HeLa cell proliferation by functional interference with cell cycle checkpoint regulators. Oncogene 1999, I 8(21):3213-3225.

94. Garner E, Raj K: Protective mechanisms of p53-p2 I-pRb proteins against DNA damage-induced cell death. Cell Cycle 2008 , 7(3):277-282

Publish with BioMed Central and every scientist can read your work free of charge

"BioMed Central will be the most significant development for disseminating the results of biomedical research in our lifetime. "

Sir Paul Nurse, Cancer Research UK

Your research papers will be:

- available free of charge to the entire biomedical community

- peer reviewed and published immediately upon acceptance

- cited in PubMed and archived on PubMed Centra

- yours - you keep the copyright 